\title{
SPHY v2.0: Spatial Processes in HYdrology
}

\author{
W. Terink ${ }^{1}$, A. F. Lutz ${ }^{1}$, G. W. H. Simons ${ }^{1,3}$, W. W. Immerzeel ${ }^{1,2}$, and P. Droogers ${ }^{1}$ \\ ${ }^{1}$ FutureWater, Costerweg 1V, 6702 AA Wageningen, the Netherlands \\ ${ }^{2}$ Utrecht University, Department of Physical Geography, Heidelberglaan 2, 3508 TC Utrecht, the Netherlands \\ ${ }^{3}$ Delft University of Technology, Faculty of Civil Engineering and Geosciences, Department of Water Management, \\ Stevinweg 1, 2628 CN Delft, the Netherlands
}

Correspondence to: W. Terink (w.terink@ futurewater.nl)

Received: 27 January 2015 - Published in Geosci. Model Dev. Discuss.: 19 February 2015

Revised: 10 June 2015 - Accepted: 21 June 2015 - Published: 08 July 2015

\begin{abstract}
This paper introduces and presents the Spatial Processes in HYdrology (SPHY) model (v2.0), its development background, its underlying concepts, and some example applications. SPHY has been developed with the explicit aim of simulating terrestrial hydrology on flexible scales, under various physiographical and hydroclimatic conditions, by integrating key components from existing and well-tested models. SPHY is a spatially distributed leaky bucket type of model, and is applied on a cell-by-cell basis. The model is written in the Python programming language using the PCRaster dynamic modeling framework. SPHY (i) integrates most hydrologic processes, (ii) has the flexibility to be applied in a wide range of hydrologic applications, and (iii) on various scales, and (iv) can easily be implemented. The most relevant hydrological processes that are integrated into the SPHY model are rainfall-runoff processes, cryosphere processes, evapotranspiration processes, the dynamic evolution of vegetation cover, lake/reservoir outflow, and the simulation of root-zone moisture contents. Studies in which the SPHY model was successfully applied and tested are described in this paper, including (i) real-time soil moisture predictions to support irrigation management in lowland areas, (ii) climate change impact studies in snow- and glacier-fed river basins, and (iii) operational flow forecasting in mountainous catchments.
\end{abstract}

\section{Introduction}

The number and diversity of water-related challenges are large and are expected to increase in the future (Wagener et al., 2010; Lall, 2014). Even today, the ideal condition of having the appropriate amount of good-quality water at the desired place and time is most often not satisfied (Biswas and Tortajada, 2010; Droogers and Bouma, 2014). It is likely that climate variability and change will intensify food insecurity by water shortages (Wheeler and von Braun, 2013), and loss of access to drinking water (Rockström et al., 2012). Current and future water-related challenges are location and time specific and can vary from impact of glacier dynamics (Immerzeel et al., 2011), economic and population growth (Droogers et al., 2012), floods or extended and more prolonged droughts (Dai, 2011), amongst others.

In response to these challenges, hydrologists and water resource specialists are developing modeling tools to analyze, understand and explore solutions to support decision makers and operational water managers (Pechlivanidis et al., 2011). Despite difficulties in connecting the scientific advances in hydrological modeling with the needs of decision makers and water managers, progress has been made and there is no doubt that modeling tools are indispensable in what is called good "water governance" (Droogers and Bouma, 2014; Liu et al., 2008).

The strength of hydrological models is that they can provide output at high temporal and spatial resolutions, and for hydrological processes that are difficult to observe on the large scale that they are generally applied on (Bastiaanssen et al., 2007). The most important aspect of applying models is in their use in exploring different scenarios, expressing for example, possible effects of changes in population and climate on the water cycle (Droogers and Aerts, 2005). Models are also applied at the operational level to explore interventions (management scenarios) to be used by water managers and policy makers. Examples of this are changes 
in reservoir operation rules, water allocation between sectors, investment in infrastructure such as water treatment or desalination plants, and agricultural and irrigation practices. In other words: models enable hydrologists and water managers to change focus from a re-active towards a pro-active approach.

Over the past decades, the land surface and hydrologic communities have made substantial progress in understanding the spatial presentation of fluxes of water and energy (Abbott et al., 1986; Wigmosta et al., 1994; Van der Kwaak and Loague, 2001; Rigon et al., 2006). Their efforts have led to the development of well-known hydrological models, such as, e.g., VIC (Liang et al., 1994, 1996), SWAT (Neitsch et al., 2009), TOPKAPI-ETH (Finger et al., 2011; Ragettli and Pellicciotti, 2012; Ragettli et al., 2014, 2015), LISFLOOD (Van Der Knijff et al., 2010), SWIM (Krysanova et al., 2015, 2000, 1998), HYPE (Lindström et al., 2010), mHM (Samaniego et al., 2010), PCR-GLOBWB (van Beek and Bierkens, 2008; Bierkens and van Beek, 2009; Wada et al., 2010; Sperna Weiland et al., 2010), MIKE-SHE (Refshaard and Storm, 1995; Oogathoo et al., 2008; Deb and Shukla, 2011) and GEOtop (Rigon et al., 2006; Endrizzi et al., 2014, 2011), amongst others. The number of existing hydrological models is probably in the tens of thousands (Droogers and Bouma, 2014). Some existing model reviews cover a substantial number of models: IRRISOFT (Irrisoft, 2014): 114; USGS (USGS, 2014): 110; EPA (EPA, 2014): 211; USACE (HEC, 2014): 18.

All these hydrological models are different with respect to (i) the number and detail of hydrological processes that are integrated, (ii) their field and (iii) scale of application, and (iv) the way they are implemented. Whereas, for example, the SWIM (Krysanova et al., 2015, 2000, 1998) and HYPE (Lindström et al., 2010) models both include all major hydrological processes, the SWIM model is typically developed for large-scale (large river basins to continental) applications, and the HYPE model operates on the sub-basin scale. Therefore, these models contain less detail, in contrast to fully distributed models operating at grid level, such as, e.g., GEOtop (Rigon et al., 2006; Endrizzi et al., 2014, 2011) and TOPKAPI-ETH (Finger et al., 2011; Ragettli and Pellicciotti, 2012; Ragettli et al., 2014, 2015). Models like, e.g., MIKE-SHE (Refshaard and Storm, 1995; Oogathoo et al., 2008; Deb and Shukla, 2011) and LISFLOOD (Van Der Knijff et al., 2010) have the advantage of being flexible in terms of the spatial and temporal resolutions, but their disadvantages are that they do not include glacier processes and that they are not open source and therefore not available to the larger community.

It is clear that all these models have their pros and cons in terms of (i) processes integrated, (ii) field of application, (iii) scale of application, and (iv) implementation. Table 1 shows the pros and cons of some well-known hydrological models, including the Spatial Processes in HYdrology (SPHY) model. Over the last couple of years we have developed the SPHY model, and improved its usefulness by applying the model in various research projects. SPHY has been developed with the explicit aim of simulating terrestrial hydrology under various physiographical and hydroclimatic conditions by integrating key components from existing and well-tested models: HydroS (Droogers and Immerzeel, 2010), SWAT (Neitsch et al., 2009), PCR-GLOBWB (van Beek and Bierkens, 2008; Bierkens and van Beek, 2009; Wada et al., 2010; Sperna Weiland et al., 2010), SWAP (van Dam et al., 1997) and HimSim (Immerzeel et al., 2011). Based on Table 1 it is clear that SPHY (i) integrates most hydrologic processes, including glacier processes, (ii) has the flexibility to study a wide range of applications, including climate and land use change impacts, irrigation planning, and droughts, (iii) can be used for catchment- and river-basinscale applications as well as farm- and country-level applications, and has a flexible spatial resolution, and (iv) can easily be implemented. Implementation of SPHY is relatively easy because (i) it is open source, (ii) input and output maps can directly be used in GIS, (iii) it is set up modular in order to switch on/off relevant/irrelevant processes and thus decreases model run time and data requirements, (iv) it needs only daily precipitation and temperature data as climate forcing, (v) it can be forced with remote sensing data, and (vi) it uses a configuration file that allows the user to change model parameters and choose the model output that needs to be reported.

The objective of this publication is to introduce and present the SPHY model and its development background, and to demonstrate some example applications. The model's executable and source codes are in the public domain (open access) and can be obtained from our website free of charge (www.sphy.nl).

\section{Model overview}

\subsection{Background}

SPHY is a spatially distributed leaky bucket type of model, and is applied on a cell-by-cell basis. The main terrestrial hydrological processes are described in a conceptual way so that changes in storages and fluxes can be assessed adequately over time and space. SPHY is written in the Python programming language using the PCRaster (Karssenberg et al., 2001, 2010; Karssenberg, 2002; Schmitz et al., 2009, 2013) dynamic modeling framework.

SPHY is grid based and cell values represent averages over a cell (Fig. 1). For glaciers, sub-grid variability is taken into account: a cell can be glacier free, partially glacierized, or completely covered by glaciers. The cell fraction not covered by glaciers consists of either land covered with snow or land that is free of snow. Land that is free of snow can consist of vegetation, bare soil, or open water. The dynamic vegetation module accounts for a time-varying fractional vegetation coverage, which affects processes such as interception, effec- 
Table 1. Pros (+) and cons (-) of some well-known hydrological models, including the SPHY model. A categorization is made between (i) processes that are integrated, (ii) field of application, (iii) scale of application, and (iv) implementation.

\begin{tabular}{|c|c|c|c|c|c|c|c|c|c|c|c|}
\hline & SPHY & $\begin{array}{l}\text { TOPKAPI- } \\
\text { ETH }\end{array}$ & SWAT & VIC & $\begin{array}{c}\text { LIS- } \\
\text { FLOOD }\end{array}$ & SWIM & HYPE & $\mathrm{mHM}$ & $\begin{array}{l}\text { MIKE- } \\
\text { SHE }\end{array}$ & $\begin{array}{c}\text { PCRGLOB- } \\
\text { WB }\end{array}$ & $\begin{array}{l}\text { GEO- } \\
\text { top }\end{array}$ \\
\hline \multicolumn{12}{|l|}{ Processes integrated } \\
\hline Rainfall-runoff & + & + & + & + & + & + & + & + & + & + & + \\
\hline Evapotranspiration & + & + & + & + & + & + & + & + & + & + & + \\
\hline $\begin{array}{l}\text { Dynamic vegetation } \\
\text { growth }\end{array}$ & + & - & + & + & + & + & $\mathrm{a}$ & NA & + & + & - \\
\hline Unsaturated zone & + & + & + & + & + & + & + & + & + & + & + \\
\hline Groundwater & + & - & + & + & + & + & + & + & + & + & + \\
\hline Glaciers & + & + & - & - & - & + & + & - & - & - & + \\
\hline Snow & + & + & + & + & + & + & + & + & + & + & + \\
\hline Routing & + & + & + & + & + & + & + & + & + & + & + \\
\hline $\begin{array}{l}\text { Lakes incorporated } \\
\text { into routing scheme }\end{array}$ & + & - & + & + & + & + & + & NA & + & + & - \\
\hline Reservoir management & - & - & + & - & - & + & + & NA & - & + & - \\
\hline \multicolumn{12}{|l|}{ Field of application } \\
\hline Climate change impacts & + & + & + & + & + & + & + & + & + & + & + \\
\hline Land use change impacts & + & + & + & + & + & + & + & + & + & + & + \\
\hline Irrigation planning & + & - & + & + & - & + & + & - & + & - & + \\
\hline Floods & - & - & - & - & $\mathrm{c}$ & - & + & - & + & + & + \\
\hline Droughts & + & + & + & + & + & + & + & + & + & + & + \\
\hline Water supply and demand & - & - & + & - & - & - & + & NA & - & - & - \\
\hline \multicolumn{12}{|l|}{ Scale of application } \\
\hline Catchment scale & + & + & + & + & - & - & + & - & + & - & + \\
\hline River basin scale & + & + & + & + & + & + & + & + & + & - & - \\
\hline Mesoscale river basins & + & - & + & + & + & + & + & + & + & + & - \\
\hline Global scale & - & - & - & + & + & - & - & - & - & + & - \\
\hline Farm level & + & - & - & - & - & - & + & - & - & - & - \\
\hline Country level & + & - & - & - & - & - & + & - & - & - & - \\
\hline Fully distributed & + & + & - & + & + & - & - & + & + & + & + \\
\hline Sub-grid variability & + & - & - & + & - & - & - & + & - & + & + \\
\hline $\begin{array}{l}\text { Flexible spatial } \\
\text { resolution }\end{array}$ & + & + & - & + & + & - & - & + & + & + & + \\
\hline Hourly resolution & - & + & + & - & + & - & + & + & + & - & + \\
\hline Sub-daily resolution & - & - & - & + & + & - & + & NA & + & - & - \\
\hline Daily resolution & + & + & + & + & + & + & + & NA & + & + & - \\
\hline \multicolumn{12}{|l|}{ Implementation } \\
\hline Open source & + & - & + & + & - & - & + & - & - & - & + \\
\hline $\begin{array}{l}\text { Forcing with } \\
\text { remote sensing }\end{array}$ & + & + & - & + & + & - & + & NA & - & - & + \\
\hline GIS compatibility & + & + & + & - & + & + & + & + & + & + & + \\
\hline Modular set up & + & - & - & + & + & + & + & + & + & - & - \\
\hline $\begin{array}{l}\text { Computational } \\
\text { efficient }\end{array}$ & + & + & + & - & + & + & + & + & - & + & + \\
\hline $\begin{array}{l}\text { Climate forcing } \\
\text { requirements }\end{array}$ & + & + & - & $\mathrm{b}$ & - & - & + & + & - & - & - \\
\hline $\begin{array}{l}\text { Flexible output } \\
\text { reporting options }\end{array}$ & + & + & - & + & + & + & + & NA & + & - & + \\
\hline $\begin{array}{l}\text { Graphical user- } \\
\text { interface in GIS }\end{array}$ & $\mathrm{a}$ & - & + & - & - & + & - & - & + & - & - \\
\hline
\end{tabular}

${ }^{a}$ Currently in development. ${ }^{\mathrm{b}}$ More climate variables are required if the model is run in energy balance mode. ${ }^{\mathrm{c}}$ Only if run in combination with LISFLOOD-FP. NA: information not available. 

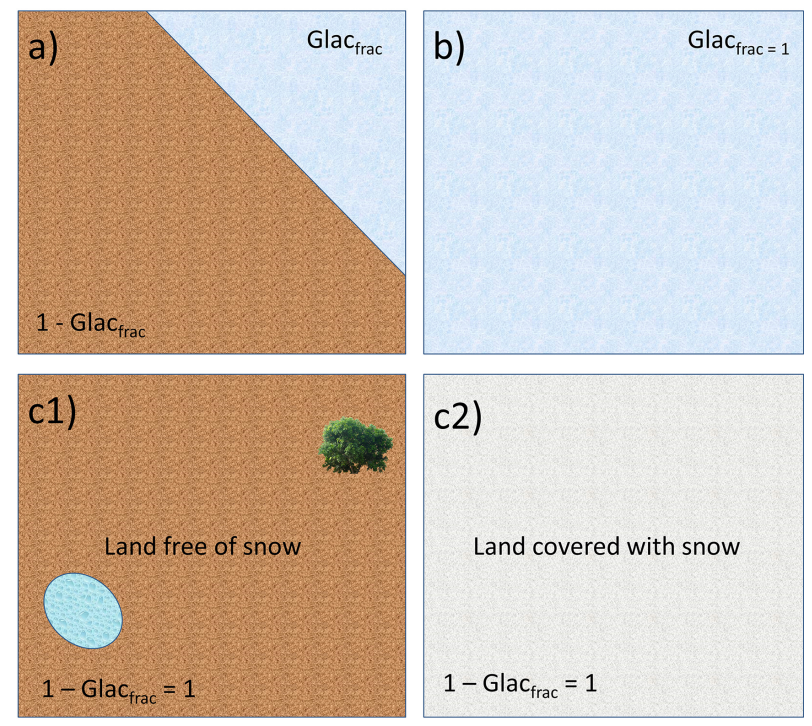

Figure 1. Illustration of SPHY sub-grid variability. A grid cell in SPHY can be (a) partially covered with glaciers, or (b) completely covered with glaciers, or (c1) free of snow, or (c2) completely covered with snow. In the case of (c1), the free land surface can consist of bare soil, vegetation, or open water.

tive precipitation, and potential evapotranspiration. Figure 2 provides a schematic overview of the SPHY modeling concepts.

The soil column structure is similar to VIC (Liang et al., 1994, 1996), with two upper soil storages and a third groundwater storage. Their corresponding drainage components are surface runoff, lateral flow and baseflow. SPHY simulates for each cell precipitation in the form of rain or snow, depending on the temperature. Precipitation that falls on land surfaces can be intercepted by vegetation and evaporated in part or whole. The snow storage is updated with snow accumulation and/or snowmelt. A part of the liquid precipitation is transformed in surface runoff, whereas the remainder infiltrates into the soil. The resulting soil moisture is subject to evapotranspiration, depending on the soil properties and fractional vegetation cover, while the remainder contributes to river discharge by means of lateral flow from the first soil layer, and baseflow from the groundwater layer.

Melting of glacier ice contributes to the river discharge by means of a slow and fast component, being (i) percolation to the groundwater layer that eventually becomes baseflow, and (ii) direct runoff. The cell-specific runoff, which becomes available for routing, is the sum of surface runoff, lateral flow, baseflow, snowmelt and glacier melt.

If no lakes are present, then the user can choose a simple flow accumulation routing scheme: for each cell, the accumulated amount of water that flows out of the cell into its neighboring downstream cell is calculated. This accumulated amount is the amount of water in the cell itself plus the amount of water in upstream cells of the cell, and is calculated using the flow direction network. If lakes are present, then the fractional accumulation flux routing scheme is used; depending on the actual lake storage, a fraction of that storage becomes available for routing and is extracted from the lake, while the remaining part becomes the updated actual lake storage. The flux available for routing is routed in the same way as in the simple flow accumulation routing scheme.

As input, SPHY requires static data as well as dynamic data. For the static data, the most relevant are digital elevation model (DEM), land use type, glacier cover, lakes/reservoirs and soil characteristics. The main dynamic data consist of climate data, such as precipitation, temperature, and reference evapotranspiration. Since SPHY is grid based, optimal use of remote sensing data and global data sources can be made. For example, the Normalized Difference Vegetation Index (NDVI) (Tucker, 1979; Carlson and Ripley, 1997; Myneni and Williams, 1994) can be used to determine the leafarea index (LAI) in order to estimate the growth stage of land cover. For setting up the model, streamflow data are not necessary. However, to undertake a proper calibration and validation procedure, flow data are required. The model could also be calibrated using actual evapotranspiration, soil moisture contents, and/or snow-covered area (SCA). Section 3.2 contains an example application in which the SPHY model has been calibrated using MODIS snow cover images. An overview of the adjustable SPHY model parameters is shown in Appendix A (Table A1).

The SPHY model provides a wealth of output variables that can be selected based on the preference of the user. Spatial output can be presented as maps of all the available hydrological processes, i.e., actual evapotranspiration, runoff generation (separated by its components), and groundwater recharge. These maps can be generated on a daily basis, but can also be aggregated at monthly or annual time periods. Time series can be generated for each cell in the study area. Time series often used are streamflow, actual evapotranspiration and recharge to the groundwater.

\subsection{Modules}

SPHY enables the user to turn on/off modules (processes) that are relevant/irrelevant for the area of interest. This concept is very useful if the user is studying hydrological processes in regions where not all hydrological processes are relevant. A user may for example be interested in studying irrigation water requirements in central Africa. For this region, glacier and snow melting processes are irrelevant, and can thus be switched off. The advantages of turning off irrelevant modules are two-fold: (i) decrease model run time, and (ii) decrease the number of required model input data. It should be noted, however, that the hydrologic model structure should be specific to the catchment's characteristics (Pomeroy et al., 2007; Clark et al., 2008; Niu et al., 2011; Essery et al., 2013; Clark et al., 2015a, b). It is therefore essen- 


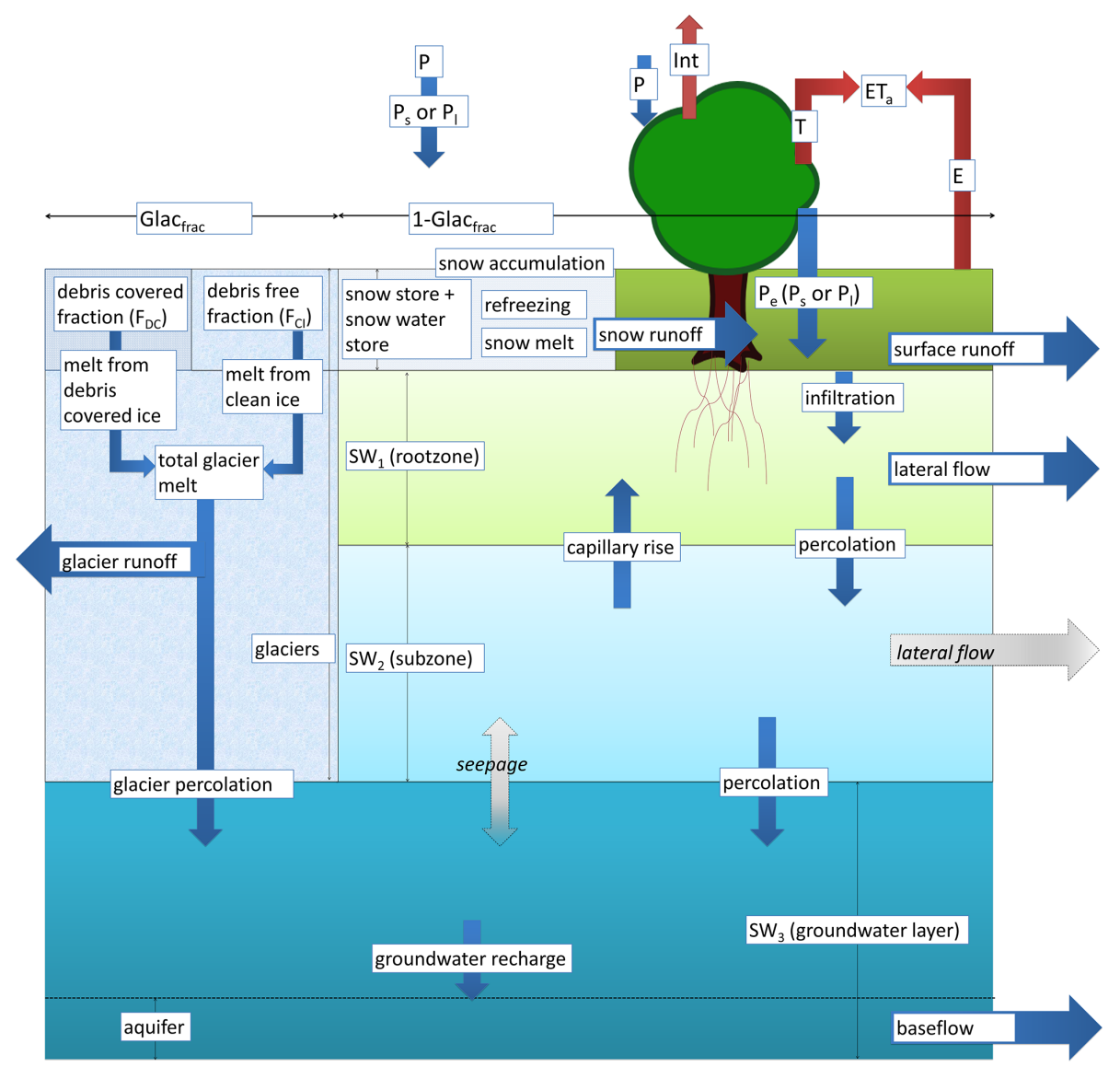

Figure 2. SPHY modeling concepts. The fluxes in grey are only incorporated when the groundwater module is not used. Abbreviations are explained in the text.

tial that the user knows which catchment characteristics and processes should be included in their modeling framework.

Figure 3 represents an overview of the six modules available: glaciers, snow, groundwater, dynamic vegetation, simple routing, and lake/reservoir routing. All modules can run independently of each other, except for the glacier module. If glaciers are present, then snow processes are relevant as well (Verbunt et al., 2003; Singh and Kumar, 1997). Since melting glacier water percolates to the groundwater layer, the glacier module cannot run with the groundwater module turned off. Two modules are available for runoff routing: (i) a simple flow accumulation routing scheme, and (ii) a fractional flow accumulation routing scheme used when lakes/reservoirs are present. The user has the option to turn off routing, or to choose between one of these two routing modules. All hydrological processes incorporated in the SPHY model are described in detail in the following sections.

\subsection{Reference and potential evapotranspiration}

Despite the good physical underlying theory of the PenmanMonteith equation (Allen et al., 1998) for calculating the reference evapotranspiration $\left(\mathrm{ET}_{\mathrm{r}}\right)$, its major limitation is the high data demand for energy-based methods. This brought Hargreaves and Samani (1985) to derive the modified Hargreaves equation that is based on temperature only. For this reason, this equation has also been implemented in the SPHY model, according to

$\mathrm{ET}_{\mathrm{r}}=0.0023 \cdot 0.408 \cdot \operatorname{Ra}\left(T_{\text {avg }}+17.8\right) \cdot \mathrm{TD}^{0.5}$,

with $\mathrm{Ra}\left(\mathrm{MJ} \mathrm{m}^{-2} \mathrm{day}^{-1}\right)$ the extraterrestrial radiation, $T_{\text {avg }}$ $\left({ }^{\circ} \mathrm{C}\right)$ the average daily air temperature, and $\mathrm{TD}\left({ }^{\circ} \mathrm{C}\right)$ the daily temperature range, defined as the difference between the daily maximum and minimum air temperature. The constant 0.408 is required to convert the units to $\mathrm{mm}$, and Ra can be obtained from tables (Allen et al., 1998) or equations using the day of the year and the latitude of the area of interest.

According to Allen et al. (1998), $\mathrm{ET}_{\mathrm{r}}$ is the evapotranspiration rate from a reference surface with access to sufficient water to allow evapotranspiration at the potential rate. The reference surface is a hypothetical grass reference crop with specific characteristics. The potential evapotranspiration $\mathrm{ET}_{\mathrm{p}}$ has no limitations on crop growth or evapotranspiration from soil water and salinity stress, crop density, pests and diseases, weed infestation or low fertility. Allen et al. (1998) deter- 


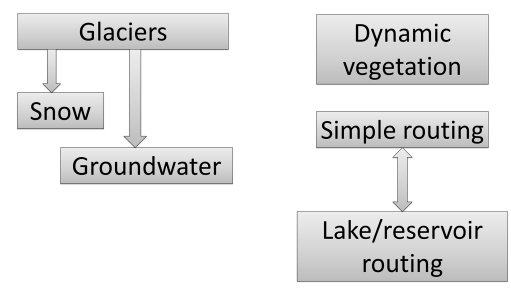

Figure 3. Modules of the SPHY model that can be switched on/off.

mined $\mathrm{ET}_{\mathrm{p}}$ by the crop coefficient approach, where the effects of various weather conditions are incorporated into $\mathrm{ET}_{\mathrm{r}}$ and the crop characteristics in the crop coefficient $(\mathrm{Kc})$, using

$\mathrm{ET}_{\mathrm{p}, t}=\mathrm{ET}_{\mathrm{r}, t} \cdot \mathrm{Kc}$,

with $\mathrm{ET}_{\mathrm{p}, t}(\mathrm{~mm})$ the potential evapotranspiration on day $t$, $\mathrm{ET}_{\mathrm{r}, t}(\mathrm{~mm})$ the reference evapotranspiration on day $t$, and $\mathrm{Kc}$ $(-)$ the crop coefficient. The effects of both crop transpiration and soil evaporation are integrated into the Kc.

If the dynamic vegetation module in SPHY is not used, then the user can opt (i) to use a single constant Kc throughout the entire simulation period or (ii) to use a pre-defined time series of crop coefficients as model input. Plausible values for Kc can be obtained from the literature (Allen et al., 1998; FAO, 2013). However, vegetation is generally very dynamic throughout the year. It is therefore more realistic to use a pre-defined time series of crop coefficients or to use the dynamic vegetation module, instead of a single constant Kc. This can be adjusted according to the user's preferences.

$\mathrm{Kc}$ can be estimated using remotely sensed data (Rafn et al., 2008; Contreras et al., 2014). In the dynamic vegetation module, $\mathrm{Kc}$ is scaled throughout the year using NDVI and the maximum and minimum values for $\mathrm{Kc}$, which are crop specific. These values for Kc can easily be obtained from Allen et al. (1998). Then Kc is calculated using

$$
\begin{gathered}
\mathrm{Kc}=\mathrm{Kc}_{\min }+\left(\mathrm{Kc}_{\max }-\mathrm{Kc}_{\min }\right) \\
\cdot \frac{\left(\mathrm{NDVI}-\mathrm{NDVI}_{\min }\right)}{\left(\mathrm{NDVI}_{\max }-\mathrm{NDVI}_{\min }\right)},
\end{gathered}
$$

with $\mathrm{NDVI}_{\max }(-)$ and $\mathrm{NDVI}_{\min }(-)$ the maximum and minimum values for NDVI (vegetation type dependent). This approach shows the flexibility of SPHY in using remote sensing data (e.g., NDVI) as input to improve model accuracy.

\subsection{Dynamic vegetation processes}

\subsubsection{Maximum canopy storage}

SPHY allows the user to use the dynamic vegetation module in order to incorporate a time-variable vegetation cover and corresponding rainfall interception. In order to calculate the rainfall interception, the canopy storage needs to be calculated, using a time series of NDVI (Carlson and Ripley, 1997). The first step involves the calculation of the fraction photosynthetically active radiation (FPAR). FPAR can
Table 2. $\mathrm{LAI}_{\max }$ values for different vegetation types (Sellers et al., 1996).

\begin{tabular}{ll}
\hline Vegetation type & LAI $_{\max }(-)$ \\
\hline Broadleaf evergreen trees & 7 \\
Broadleaf deciduous trees & 7 \\
Mixed trees & 7.5 \\
Needleleaf evergreen trees & 8 \\
High latitude deciduous trees & 8 \\
Grass with 10-40\% woody cover & 5 \\
Grass with < 10\% woody cover & 5 \\
Shrubs and bare soil & 5 \\
Moss and lichens & 5 \\
Bare & 5 \\
Cultivated & 6 \\
\hline
\end{tabular}

be calculated using a relation between NDVI and FPAR, which was found by Peng et al. (2012) and described by Sellers et al. (1996), according to

$$
\begin{aligned}
\mathrm{FPAR} & =\min \left(\frac{\left(\mathrm{SR}-\mathrm{SR}_{\min }\right)\left(\mathrm{FPAR}_{\max }-\mathrm{FPAR}_{\min }\right)}{\left(\mathrm{SR}_{\max }-\mathrm{SR}_{\min }\right)}\right. \\
& \left.+\mathrm{FPAR}_{\min }, 0.95\right)
\end{aligned}
$$

with

$\mathrm{SR}=\frac{1+\mathrm{NDVI}}{1-\mathrm{NDVI}}$,

and FPAR $_{\max }(-)$ and FPAR $_{\min }(-)$ having values of 0.95 and 0.001 , respectively. An FPAR of 0.95 is equivalent to the maximum LAI for a particular class, and an FPAR of 0.001 is equivalent to a minimum LAI. In order to calculate FPAR, an NDVI time series is required.

The second step is the calculation of the leaf-area index (LAI), which is eventually required to calculate the maximum canopy storage $\left(\mathrm{Scan}_{\mathrm{max}}\right)$. According to Monteith (1973), LAI for vegetation that is evenly distributed over a surface can be calculated using a logarithmic relation between LAI and FPAR, according to

$$
\mathrm{LAI}=\mathrm{LAI}_{\max } \cdot \frac{\log (1-\text { FPAR })}{\log \left(1-\mathrm{FPAR}_{\max }\right)},
$$

with LAI (-) the leaf-area index, and $\mathrm{LAI}_{\max }(-)$ the maximum leaf-area index (vegetation type dependent). This means that the maximum and minimum LAI values are related to the maximum and minimum of FPAR. Table 2 shows the $\mathrm{LAI}_{\max }$ values for a certain number of vegetation types.

For vegetation that is concentrated in clusters, the linear relation from Goward and Huemmrich (1992) is often used. However, since SPHY is generally applied using grid-cell resolutions between $250 \mathrm{~m}$ and $1 \mathrm{~km}$, we can assume that the effect of having vegetation concentrated in clusters is negligible. Therefore, the calculation of LAI in SPHY is done using the logarithmic relation of Monteith (1973) (Eq. 6). 
The next step involves the calculation of the maximum canopy storage ( $\left.\operatorname{Scan}_{\max }(\mathrm{mm})\right)$. Many different relations between $\mathrm{Scan}_{\max }$ and LAI can be found in the literature, depending on the vegetation type (de Jong and Jetten, 2010). The best results for crop canopies are shown by Kozak et al. (2007) and are archived by Von Hoyningen-Huene (1981), who derived the following relation between $\operatorname{Scan}_{\max }$ and LAI:

$\operatorname{Scan}_{\max }=0.935+0.498 \mathrm{LAI}-0.00575 \mathrm{LAI}^{2}$.

\subsubsection{Interception}

Interception is calculated on a daily basis if the dynamic vegetation module is used, and consists of the daily precipitation plus the intercepted water remaining in the canopy storage from the previous day. First, the canopy storage is updated with the amount of precipitation of the current day:

$\operatorname{Scan}_{t}=\operatorname{Scan}_{t-1}+P_{t}$

with $\operatorname{Scan}_{t}(\mathrm{~mm})$ the canopy storage on day $t, \operatorname{Scan}_{t-1}(\mathrm{~mm})$ the canopy storage on day $t-1$, and $P_{t}(\mathrm{~mm})$ the amount of precipitation on day $t$. The portion of precipitation that cannot be stored in the canopy storage is known as precipitation throughfall, or effective precipitation, according to

$\mathrm{Pe}_{t}=\max \left(0, \operatorname{Scan}_{t}-\operatorname{Scan}_{\max , t}\right)$,

with $\mathrm{Pe}_{t}(\mathrm{~mm})$ the effective precipitation on day $t$, and $\mathrm{Scan}_{t}$ $(\mathrm{mm})$ the canopy storage on day $t$. This equation shows that precipitation throughfall only occurs if the water stored in the canopy exceeds the maximum canopy storage. After the effective precipitation has been calculated, the canopy storage is updated as

$\mathrm{Scan}_{t}=\mathrm{Scan}_{t}-\mathrm{Pe}_{t}$.

The remaining amount of water stored in the canopy is available for interception, and the amount of water that will be intercepted depends on the atmospheric demand for open water evaporation. A commonly used value for the atmospheric demand for open water evaporation is 1.5 (Allen et al., 1998), which is derived from the ratio between 1 and the mean pan evaporation coefficient $\mathrm{Kp}(\sim 0.65)$. The interception can now be calculated using

$\operatorname{Int}_{t}=\min \left(1.5 \mathrm{ET}_{\mathrm{r}, t}, \operatorname{Scan}_{t}\right)$,

with $\mathrm{Int}_{t}(\mathrm{~mm})$ the intercepted water on day $t$, and $\mathrm{ET}_{\mathrm{r}, t}$ $(\mathrm{mm})$ the reference evapotranspiration on day $t$. Finally, the canopy storage is updated by subtracting the interception:

$\operatorname{Scan}_{t}=\operatorname{Scan}_{t}-\operatorname{Int}_{t}$.

\subsection{Snow processes}

For each cell, a dynamic snow storage is simulated at a daily time step, adopted from the model presented by Kokkonen et al. (2006). The model keeps track of a snow storage, which is fed by precipitation and generates runoff from snowmelt. Refreezing of snowmelt and rainfall within the snowpack are simulated as well.

\subsubsection{Snow and rainfall}

Depending on a temperature threshold, precipitation is defined as falling in either solid or liquid form. Daily snow accumulation, which is defined as solid precipitation, is calculated as

$P_{\mathrm{s}, t}=\left\{\begin{array}{lll}\mathrm{Pe}_{t} & \text { if } & T_{\mathrm{avg}, t} \leq T_{\text {crit }} \\ 0 & \text { if } & T_{\mathrm{avg}, t}>T_{\text {crit }}\end{array}\right\}$,

with $P_{\mathrm{s}, t}(\mathrm{~mm})$ the snowfall on day $t, \mathrm{Pe}_{t}(\mathrm{~mm})$ the effective precipitation on day $t, T_{\text {avg, } t}\left({ }^{\circ} \mathrm{C}\right)$ the mean air temperature on day $t$, and $T_{\text {crit }}\left({ }^{\circ} \mathrm{C}\right)$ a calibrated temperature threshold for precipitation to fall as snow. The precipitation that falls as rain is defined as liquid precipitation, and is calculated as

$P_{l, t}=\left\{\begin{array}{lll}\mathrm{Pe}_{t} & \text { if } & T_{\text {avg }, t}>T_{\text {crit }} \\ 0 & \text { if } & T_{\text {avg }, t} \leq T_{\text {crit }}\end{array}\right\}$,

with $P_{l, t}(\mathrm{~mm})$ being the amount of rainfall on day $t$.

\subsubsection{Snowmelt, refreezing, and storage}

To simulate snowmelt, the well-established and widely used degree-day melt modeling approach is used (Hock, 2003). The application of degree-day models is widespread in cryospheric models and is based on an empirical relationship between melt and air temperature. Degree-day models are easier to set up compared to energy-balance models, and only require air temperature, which is mostly available and relatively easy to interpolate (Hock, 2005). Using a degreeday modeling approach, the daily potential snowmelt is calculated as follows:

$A_{\mathrm{pot}, t}=\left\{\begin{array}{lll}T_{\mathrm{avg}, t} \cdot \mathrm{DDF}_{S} & \text { if } & T_{\mathrm{avg}, t}>0 \\ 0 & \text { if } & T_{\mathrm{avg}, t} \leq 0\end{array}\right\}$,

with $A_{\mathrm{pot}, t}(\mathrm{~mm})$ the potential snowmelt on day $t$, and $\mathrm{DDF}_{s}$ $\left(\mathrm{mm}^{\circ} \mathrm{C}^{-1} \mathrm{day}^{-1}\right)$ a calibrated degree-day factor for snow. The actual snowmelt is limited by the snow storage at the end of the previous day, and is calculated as

$A_{\text {act }, t}=\min \left(A_{\text {pot }, t}, \mathrm{SS}_{t-1}\right)$,

with $A_{\text {act, } t}(\mathrm{~mm})$ the actual snowmelt on day $t$, and $\mathrm{SS}_{t-1}$ $(\mathrm{mm})$ the snow storage on day $t-1$. The snow storage from day $t-1$ is then updated to the current day $t$, using the actual snowmelt $\left(A_{\text {act }, t}\right)$ and the solid precipitation $\left(P_{\mathrm{s}, t}\right)$. Part of the actual snowmelt freezes within the snowpack and thus does not run off immediately. When temperature is below the melting point, meltwater that has frozen in the snowpack during $t-1$ is added to the snow storage as

$\mathrm{SS}_{t}=\left\{\begin{array}{ll}\mathrm{SS}_{t-1}+P_{\mathrm{s}, t}+\mathrm{SSW}_{t-1} & \text { if } \quad T_{\mathrm{avg}, t}<0 \\ \mathrm{SS}_{t-1}+P_{\mathrm{s}, t}-A_{\text {act }, t} & \text { if } \quad T_{\mathrm{avg}, t} \geq 0\end{array}\right\}$, 
with $\mathrm{SS}_{t}$ the snow storage on day $t, \mathrm{SS}_{t-1}$ the snow storage on day $t-1, P_{\mathrm{s}, t}$ the solid precipitation on day $t, A_{\text {act }, t}$ the actual snowmelt on day $t$, and $\mathrm{SSW}_{t-1}$ the amount of frozen meltwater on day $t-1$. The units for all terms are $\mathrm{mm}$.

The capacity of the snowpack to freeze snowmelt is characterized by introducing a calibrated water storage capacity (SSC $\left(\mathrm{mm} \mathrm{mm}^{-1}\right)$ ), which is the total water equivalent of snowmelt $(\mathrm{mm})$ that can freeze per $\mathrm{mm}$ water equivalent of snow in the snow storage. The maximum of meltwater that can freeze $\left(\mathrm{SSW}_{\max }(\mathrm{mm})\right)$ is thus limited by the thickness of the snow storage:

$\mathrm{SSW}_{\max , t}=\mathrm{SSC} \cdot \mathrm{SS}_{t}$.

Then the amount of meltwater stored in the snowpack, and that can freeze in the next time step, is calculated as

$\mathrm{SSW}_{t}=$

$$
\left\{\begin{array}{lll}
0 & \text { if } & T_{\text {avg }, t}<0 \\
\min \left(\mathrm{SSW}_{\max , t}, \mathrm{SSW}_{t-1}\right. & \text { if } & T_{\text {avg }, t} \geq 0
\end{array}\right\}
$$

with $\mathrm{SSW}_{t}$ the amount of meltwater in the snowpack on day $t, \mathrm{SSW}_{\max , t}$ the maximum of meltwater that can freeze on day $t, \mathrm{SSW}_{t-1}$ the amount of frozen meltwater on day $t-$ $1, P_{l, t}$ the amount of rainfall on day $t$, and $A_{\text {act }, t}$ the actual snowmelt on day $t$. The units of all terms are in $\mathrm{mm}$.

The total snow storage (SST (mm)) consists of the snow storage and the meltwater that can freeze within it, according to

$\mathrm{SST}_{t}=\left(\mathrm{SS}_{t}+\mathrm{SSW}_{t}\right) \cdot(1-\mathrm{GlacF})$,

with $(1-\mathrm{GlacF})(-)$ the grid-cell fraction not covered with glaciers. In SPHY it is therefore assumed that snow accumulation and snowmelt can only occur on the grid-cell fraction determined as land surface. Snow falling on glaciers is incorporated in the glacier module.

\subsubsection{Snow runoff}

Runoff from snow (SRo (mm)) is generated when the air temperature is above melting point and no more meltwater can be frozen within the snowpack, according to

$\mathrm{SRo}_{t}=\left\{\begin{array}{lll}A_{\mathrm{act}, t}+P_{l, t}-\Delta \mathrm{SSW} & \text { if } & T_{\mathrm{avg}, t}>0 \\ 0 & \text { if } & T_{\mathrm{avg}, t} \leq 0\end{array}\right\}$,

with $\Delta \mathrm{SSW}(\mathrm{mm})$ the change in meltwater stored in the snowpack according to

$\Delta \mathrm{SSW}=\mathrm{SSW}_{t}-\mathrm{SSW}_{t-1}$.

\subsection{Glacier processes}

Since the SPHY model usually operates at a spatial resolution between $250 \mathrm{~m}$ and $1 \mathrm{~km}$, the dynamics of glaciers such as ice flow cannot be resolved explicitly. Therefore, glaciers in SPHY are considered melting surfaces that can completely or partly cover a grid cell.

\subsubsection{Glacier melt}

Glacier melt is calculated with a degree-day modeling approach as well (Hock, 2005). Because glaciers that are covered with debris melt at different rates than debris-free glaciers (Reid et al., 2012), a distinction can be made between different degree-day factors for both types. The daily melt from debris-free glaciers $\left(A_{\mathrm{CI}}(\mathrm{mm})\right)$ is calculated as

$A_{\mathrm{CI}, t}=\left\{\begin{array}{lll}T_{\mathrm{avg}, t} \cdot \mathrm{DDF}_{\mathrm{CI}} \cdot F_{\mathrm{CI}} & \text { if } & T_{\mathrm{avg}, t}>0 \\ 0 & \text { if } & T_{\mathrm{avg}, t} \leq 0\end{array}\right\}$,

with $\mathrm{DDF}_{\mathrm{CI}}\left(\mathrm{mm}^{\circ} \mathrm{C}^{-1} \mathrm{day}^{-1}\right)$ a calibrated degree-day factor for debris-free glaciers and $F_{\mathrm{CI}}(-)$ the fraction of debrisfree glaciers within the fractional glacier cover $(\mathrm{GlacF})$ of a grid cell. The daily melt from debris-covered glaciers $\left(A_{\mathrm{DC}}\right.$ $(\mathrm{mm}))$ is calculated in a similar way, but with a different degree-day factor:

$A_{\mathrm{DC}, t}=\left\{\begin{array}{lll}T_{\mathrm{avg}, t} \cdot \mathrm{DDF}_{\mathrm{DC}} \cdot F_{\mathrm{DC}} & \text { if } & T_{\mathrm{avg}, t}>0 \\ 0 & \text { if } & T_{\mathrm{avg}, t} \leq 0\end{array}\right\}$,

where $\mathrm{DDF}_{\mathrm{DC}}\left(\mathrm{mm}^{\circ} \mathrm{C}^{-1} \mathrm{day}^{-1}\right)$ is a degree-day factor for debris-covered glaciers and $F_{\mathrm{DC}}(-)$ is the fraction of debriscovered glaciers within the fractional glacier cover of a grid cell. The total glacier melt per grid cell $\left(A_{\mathrm{GLAC}}(\mathrm{mm})\right)$ is then calculated by summing the melt from the debris-covered and debris-free glacier types and multiplying by the fractional glacier cover, according to

$A_{\mathrm{GLAC}, t}=\left(A_{\mathrm{CI}, t}+A_{\mathrm{DC}, t}\right) \cdot \mathrm{GlacF}$.

\subsubsection{Glacier runoff}

In SPHY, a fraction of the glacier melt percolates to the groundwater while the remaining fraction runs off. The distribution of both is defined by a calibrated glacier melt runoff factor (GlacROF (-)) that can have any value ranging from 0 to 1 . Thus, the generated runoff GRo ( $\mathrm{mm}$ ) from glacier melt is defined as

$\mathrm{GRo}_{t}=A_{\mathrm{GLAC}, t} \cdot$ GlacROF.

\subsubsection{Glacier percolation}

The percolation from glacier melt to the groundwater $\left(G_{\text {perc }}\right.$ $(\mathrm{mm})$ ) is defined as

$G_{\mathrm{perc}, t}=A_{\mathrm{GLAC}, t} \cdot(1-\mathrm{GlacROF})$.

The percolated glacier water is added to the water that percolates from the soil layers of the non-glacierized part of the grid cell (Sects. 2.7.1 and 2.7.6), which eventually recharges the groundwater.

\subsection{Soil water processes}

\subsubsection{Soil water balances}

The soil water processes in SPHY are modeled for three soil layers (Fig. 2), being (i) the first soil layer (root zone), 
(ii) second soil layer (subzone), and (iii) third soil layer (groundwater layer). The water balance of the first soil layer is

$$
\begin{aligned}
\mathrm{SW}_{1, t} & =\mathrm{SW}_{1, t-1}+\mathrm{Pe}_{t}-\mathrm{ET}_{\mathrm{a}, t}-\mathrm{RO}_{t}-\mathrm{LF}_{1, t} \\
& -\mathrm{Perc}_{1, t}+\mathrm{Cap}_{t},
\end{aligned}
$$

with $\mathrm{SW}_{1, t}$ and $\mathrm{SW}_{1, t-1}$ the water content in the first soil layer on days $t$ and $t-1$, respectively, $\mathrm{Pe}_{t}$ the effective precipitation on day $t, \mathrm{ET}_{\mathrm{a}, t}$ the actual evapotranspiration on day $t, \mathrm{RO}_{t}$ the surface runoff on day $t, \mathrm{LF}_{1, t}$ the lateral flow from the first soil layer on day $t, \operatorname{Perc}_{1, t}$ the percolation from the first to the second soil layer on day $t$, and $\mathrm{Cap}_{t}$ the capillary rise from the second to the first soil layer on day $t$. The second soil layer water balance is

$\mathrm{SW}_{2, t}=\mathrm{SW}_{2, t-1}+\operatorname{Perc}_{1, t}-\mathrm{Perc}_{2, t}-\mathrm{Cap}_{t}$,

with $\mathrm{SW}_{2, t}$ and $\mathrm{SW}_{2, t-1}$ the water content in the second soil layer on day $t$ and $t-1$, respectively, and $\operatorname{Perc}_{2, t}$ percolation from the second to the third soil layer on day $t$. The third soil layer water balance is given as

$\mathrm{SW}_{3, t}=\mathrm{SW}_{3, t-1}+\mathrm{Gchrg}_{t}-\mathrm{BF}_{t}$,

with $\mathrm{SW}_{3, t}$ and $\mathrm{SW}_{3, t-1}$ the water content in the third soil layer on day $t$ and $t-1$, respectively, $\mathrm{Gchrg}_{t}$ groundwater recharge from the second to the third soil layer on day $t$, and $\mathrm{BF}_{t}$ baseflow on day $t$. If the glacier module is used, then groundwater recharge consists of percolation from the second soil layer and percolated glacier melt; otherwise, only percolation from the second soil layer is taken into account.

The user can opt to run SPHY without the third soil layer (groundwater). This may be desirable if the user for example is mainly interested in simulating soil moisture conditions in the root zone, instead of evaluating for instance the contribution of baseflow to the total routed river flow. In that case, only the two upper soil layers are used where the bottom boundary of soil layer two is controlled by a seepage flux (positive outward), and instead of baseflow from the third soil layer, water leaves the second soil layer through lateral flow. With the groundwater module turned off, the water balance for the second soil layer is

$\mathrm{SW}_{2, t}=\mathrm{SW}_{2, t-1}+\mathrm{Perc}_{1, t}-\mathrm{LF}_{2, t}-\mathrm{Cap}_{t}-$ Seep,

with $\mathrm{LF}_{2, t}$ lateral flow from the second soil layer, and Seep seepage in or out of the second soil layer (positive is outgoing). The units for all water balance terms are in $\mathrm{mm}$.

\subsubsection{Actual evapotranspiration}

Evapotranspiration refers to both the transpiration from vegetation and the evaporation from soil or open water. As was mentioned in Sect. 2.3, the Kc accounts for both the crop transpiration and soil evaporation. The additional use of the dynamic vegetation module accounts for a time-variable vegetation cover, meaning that the role of evaporation becomes more dominant as soon as vegetation cover decreases.

Many limiting factors (e.g., salinity stress, water shortage, water excess, diseases) can cause a reduction in potential evapotranspiration $\left(\mathrm{ET}_{\mathrm{p}}\right)$, resulting in the actual evapotranspiration rate $\left(\mathrm{ET}_{\mathrm{a}}\right)$. Since SPHY is a water-balance model, SPHY only accounts for stresses related to water shortage or water excess. If there is too much water in the soil profile, then the plant is unable to extract water because of oxygen stress (Bartholomeus et al., 2008). The calculation of evapotranspiration reduction due to water excess (oxygen stress) is quite complex and requires a substantial number of plant and soil properties (e.g., soil temperature, root dry weight, plant respiration, and minimum gas filled soil porosity; Bartholomeus et al., 2008) that are generally not available for the spatial scale that SPHY is applied on. Therefore, SPHY uses an evapotranspiration reduction parameter $\left(\right.$ ETred $\left._{w e t}\right)$ that has a value of 0 if the soil is saturated, and otherwise it will have a value of 1 . This parameter is used in the following equation to calculate the actual evapotranspiration:

$\mathrm{ET}_{\mathrm{a}, t}=\mathrm{ET}_{\mathrm{p}, t} \cdot \mathrm{ETred}_{\mathrm{wet}} \cdot \mathrm{ETred}_{\mathrm{dry}}$,

with $\mathrm{ET}_{\mathrm{a}, t}(\mathrm{~mm})$ the actual evapotranspiration on day $t, \mathrm{ET}_{\mathrm{p}, t}$ $(\mathrm{mm})$ the potential evapotranspiration on day $t$, and ETred $_{\text {wet }}$ and ETred $_{\text {dry }}$ the reduction parameters for water excess and water shortage conditions, respectively. ETred $_{\text {dry }}$ is calculated using the Feddes equation (Feddes et al., 1978), which assumes a linear decline in rootwater uptake if the water pressure head drops below a critical value. This critical value can be determined using the soil water retention curve ( $\mathrm{pF}$ curve), which relates the moisture content of the soil to its binding capacity. This relation is unique for each soil type. The binding capacity is a suction force $(H)$ and is therefore often expressed in cm negative water column. The $\mathrm{pF}$ value is simply a conversion of the suction force $(H)$, and is calculated as

$\mathrm{pF}=\log _{10}(-H)$.

Soils that are at field capacity generally have a $\mathrm{pF}$ of 2 , meaning $-100 \mathrm{~cm}$ of water column, and soils that are at permanent wilting point have a $\mathrm{pF}$ of 4.2 , or $-16000 \mathrm{~cm}$ of water column. The permanent wilting point is often referred to as the point where the crop dies. In SPHY it is assumed that the linear decline in rootwater uptake starts at a pF of $3(-1000 \mathrm{~cm}$ water column). Therefore, $\operatorname{ETred}_{\text {dry }}(-)$ is calculated as

$\mathrm{ETred}_{\mathrm{dry}, t}=\frac{\mathrm{SW}_{1, t}-\mathrm{SW}_{1, \mathrm{pF} 4.2}}{\mathrm{SW}_{1, \mathrm{pF} 3}-\mathrm{SW}_{1, \mathrm{pF} 4.2}}$,

with $\operatorname{ETred}_{\mathrm{dry}, t}(-)$ the reduction in rootwater uptake due to water shortage on day $t, \mathrm{SW}_{1, t}(\mathrm{~mm})$ the actual soil water content in the first soil layer on day $t$, and $\mathrm{SW}_{1, \mathrm{pF} 3}(\mathrm{~mm})$ and $\mathrm{SW}_{1, \mathrm{pF} 4}(\mathrm{~mm})$ the soil water content in the first soil layer at 
pF3 and pF4, respectively. ETred $_{\text {dry }}$ can therefore have values ranging between 0 and 1 , where a value of 1 represents optimal plant growing conditions, and 0 means no rootwater uptake at all. ETred $\mathrm{d}_{\text {dry }}$ is eventually used in Eq. (32) to calculate the $\mathrm{ET}_{\mathrm{a}}$.

\subsubsection{Surface runoff}

Since the SPHY model runs on a daily time step, the model does not account for sub-daily variability in rainfall intensities. Therefore, the Hortonian runoff process (Beven, 2004; Corradini et al., 1998), which refers to infiltration excess overland flow, is considered less important. For this reason, SPHY uses the saturation excess overland flow process, known as Hewlettian runoff (Hewlett, 1961), to calculate surface runoff. Surface runoff is calculated from the first soil layer:

$\mathrm{RO}=\left\{\begin{array}{lll}\mathrm{SW}_{1}-\mathrm{SW}_{1, \mathrm{sat}} & \text { if } \quad \mathrm{SW}_{1}>\mathrm{SW}_{1, \mathrm{sat}} \\ 0 & \text { if } \quad \mathrm{SW}_{1} \leq \mathrm{SW}_{1, \mathrm{sat}}\end{array}\right\}$,

with RO (mm) surface runoff, $\mathrm{SW}_{1}(\mathrm{~mm})$ the water content in the first soil layer, and $\mathrm{SW}_{1 \text {, sat }}(\mathrm{mm})$ the saturated water content of the first soil layer.

\subsubsection{Lateral flow}

Lateral flow is substantial in catchments with steep gradients and soils with high hydraulic conductivities (Beven, 1981; Beven and Germann, 1982; Sloan and Moore, 1984). In SPHY, it is assumed that only the amount of water exceeding field capacity can be used for lateral flow. Therefore, the drainable volume of water (excess water) needs to be calculated first:

$W_{l, \text { exc }}=\left\{\begin{array}{lll}\mathrm{SW}_{l}-\mathrm{SW}_{l, \mathrm{fc}} & \text { if } \quad \mathrm{SW}_{l}>\mathrm{SW}_{l, \mathrm{fc}} \\ 0 & \text { if } \quad \mathrm{SW}_{l} \leq \mathrm{SW}_{l, \mathrm{fc}}\end{array}\right\}$,

with $W_{l \text {,exc }}(\mathrm{mm})$ the drainable volume of water from soil layer $l, \mathrm{SW}_{l}(\mathrm{~mm})$ the water content in soil layer $l$, and $\mathrm{SW}_{l, \mathrm{fc}}$ (mm) the field capacity of soil layer $l$. According to Sloan and Moore (1984), the lateral flow at the hillslope outlet can be calculated as

$\mathrm{LF}_{l}^{*}=W_{l, \text { excfrac }} \cdot v_{\text {lat }, l}$,

with $\mathrm{LF}_{l}^{*}(\mathrm{~mm})$ lateral flow from soil layer $l, W_{l \text {,excfrac }}(-)$ the drainable volume of water as a fraction of the saturated volume, and $v_{\text {lat }, l}\left(\mathrm{~mm} \mathrm{day}^{-1}\right)$ the flow velocity at the outlet. In SPHY, the drainable volume as a fraction of the saturated volume is calculated as

$W_{l, \text { excfrac }}=\frac{W_{l, \text { exc }}}{\mathrm{SW}_{l, \mathrm{sat}}-\mathrm{SW}_{l, \mathrm{fc}}}$.

The velocity of flow at the outlet, $v_{\text {lat, } l}\left(\mathrm{~mm} \mathrm{day}^{-1}\right)$, depends on both the saturated hydraulic conductivity $K_{\text {sat, } l}$ $\left(\mathrm{mm} \mathrm{day}^{-1}\right)$ and the slope of the hill slp (-), and is defined as

$v_{\text {lat }, l}=K_{\mathrm{sat}, l} \cdot \operatorname{slp}$.
The slope (slp) in SPHY is calculated for each grid cell as the increase in elevation per unit distance.

According to Neitsch et al. (2009), only a fraction of lateral flow will reach the main channel on the day it is generated if the catchment of interest has a time of concentration greater than 1 day. This concept is also implemented in the SPHY model, and uses a lateral flow travel time $\mathrm{TT}_{\mathrm{lag}, l}(\mathrm{~d})$ to lag a portion of lateral flow release to the channel:

$\mathrm{LF}_{l}=\left(\mathrm{LF}_{l}^{*}+\mathrm{LF}_{l, t-1}^{*}\right) \cdot\left(1-\exp \left[\frac{-1}{\mathrm{TT}_{\text {lag }, l}}\right]\right)$,

with $\mathrm{LF}_{l}(\mathrm{~mm})$ the amount of lateral flow entering the channel on a given day, $\mathrm{LF}_{l}^{*}(\mathrm{~mm})$ the lateral flow (Eq. 37) generated within the cell on a given day, and $\mathrm{LF}_{l, t-1}^{*}(\mathrm{~mm})$ the lateral flow lagged from the previous day. SPHY assumes the lateral flow travel time to be dependent on the field capacity $\mathrm{SW}_{l, \mathrm{fc}}(\mathrm{mm})$, saturated content $\mathrm{SW}_{l \text {, sat }}(\mathrm{mm})$, and the saturated conductivity $K_{\mathrm{sat}, l}\left(\mathrm{~mm} \mathrm{day}^{-1}\right)$, according to

$\mathrm{TT}_{\text {lag }, l}=\frac{\mathrm{SW}_{l, \mathrm{sat}}-\mathrm{SW}_{l, \mathrm{fc}}}{K_{\mathrm{sat}, l}}$.

A longer lateral flow travel time will result in a smoother streamflow hydrograph.

\subsubsection{Percolation}

If the groundwater module is used, then water can percolate from the first to the second soil layer, and from the second to the third soil layer. If the user decides to run SPHY without the groundwater module, percolation only occurs from the first to the second soil layer. In SPHY, water can only percolate if the water content exceeds the field capacity of that layer, and the water content of the underlying layer is not saturated. A similar approach has been used in the SWAT model (Neitsch et al., 2009). The water volume available for percolation to the underlying layer is calculated as

$$
\begin{aligned}
& W_{l, \text { exc }}= \\
& \begin{cases}0 & \text { if } \mathrm{SW}_{l} \leq \mathrm{SW}_{l, \mathrm{fc}} \text { or } \\
& \mathrm{SW}_{l+1} \geq \mathrm{SW}_{l+1, \mathrm{sat}} \\
\mathrm{SW}_{l+1, \mathrm{sat}}-\mathrm{SW}_{l+1} & \text { if } \mathrm{SW}_{l}-\mathrm{SW}_{l, \mathrm{fc}}> \\
\mathrm{SW}_{l}-\mathrm{SW}_{l, \mathrm{fc}} & \begin{array}{l}
\mathrm{SW}_{l+1, \mathrm{sat}}-\mathrm{SW}_{l+1} \\
\text { else }
\end{array}\end{cases}
\end{aligned}
$$

with $W_{l, \text { exc }}(\mathrm{mm})$ the drainable volume of water from layer $l, \mathrm{SW}_{l}(\mathrm{~mm})$ the water content in layer $l, \mathrm{SW}_{l, \mathrm{fc}}(\mathrm{mm})$ the field capacity of layer $l, \mathrm{SW}_{l+1}(\mathrm{~mm})$ the water content in layer $l+1$, and $\mathrm{SW}_{l+1, \text { sat }}(\mathrm{mm})$ the saturated water content of layer $l+1$. Only a certain amount of $\mathrm{W}_{l \text {, exc }}$ will percolate to the underlying soil layer, depending on the percolation travel time $\mathrm{TT}_{\text {perc, } l}(\mathrm{~d})$. This approach follows the storage routing methodology, which is also implemented in the SWAT model (Neitsch et al., 2009):

$w_{l, \text { perc }}=W_{l, \operatorname{exc}} \cdot\left(1-\exp \left[\frac{-1}{\mathrm{TT}_{\text {perc }, l}}\right]\right)$, 
with $w_{l, \text { perc }}(\mathrm{mm})$ the amount of water percolating to the underlying soil layer. Since the speed at which water can move through the soil is mainly dependent on the saturated hydraulic conductivity ( $K_{\text {sat }}$ ), the travel time for percolation is calculated the same way as the travel time for lateral flow (Eq. 41).

\subsubsection{Groundwater recharge}

Water that percolates from the second to the third soil layer will eventually reach the shallow aquifer. This process is referred to as groundwater recharge hereafter. If the glacier module is used as well, then glacier melt that percolates also contributes to the groundwater recharge. Groundwater recharge often does not occur instantaneously, but with a time lag that depends on the depth of the groundwater table and soil characteristics. SPHY uses the same exponential decay weighting function as proposed by Venetis (1969) and used by Sangrey et al. (1984) in a precipitation groundwater response model. This approach has also been adopted in the SWAT model (Neitsch et al., 2009), using

$\operatorname{Gchrg}_{t}=\left(1-\exp ^{\frac{-1}{\delta \mathrm{gw}}}\right) \cdot w_{2, \text { perc }}+\exp ^{\frac{-1}{\delta \mathrm{gw}}} \cdot \mathrm{Gchrg}_{t-1}$,

with $\mathrm{Gchrg}_{t}(\mathrm{~mm})$ and $\mathrm{Gchrg}_{t-1}(\mathrm{~mm})$ the groundwater recharge on days $t$ and $t-1$, respectively. $\delta_{\mathrm{gw}}(\mathrm{d})$ is the delay time and $w_{2 \text {,perc }}(\mathrm{mm})$ is the amount of water that percolates from the second to the third layer on day $t$.

\subsubsection{Baseflow}

After groundwater recharge has been calculated, SPHY calculates baseflow, which is defined as the flow going from the shallow aquifer to the main channel. Baseflow only occurs when the amount of water stored in the third soil layer exceeds a certain threshold $\left(\mathrm{BF}_{\text {thresh }}\right)$ that can be specified by the user. Baseflow calculation in SPHY is based on the steady-state response of groundwater flow to recharge (Hooghoudt, 1940) and the water table fluctuations that are a result of the non-steady response of groundwater flow to periodic groundwater recharge (Smedema and Rycroft, 1983). The SWAT model (Neitsch et al., 2009) assumes a linear relation between the variation in groundwater flow (baseflow) and the rate of change in water table height, according to

$$
\frac{\mathrm{dBF}}{\mathrm{d} t}=10 \cdot \frac{K_{\mathrm{sat}}}{\mu L_{\mathrm{gw}}^{2}} \cdot(\mathrm{Gchrg}-\mathrm{BF})=\alpha_{\mathrm{gw}} \cdot(\mathrm{Gchrg}-\mathrm{BF}),
$$

with $\mathrm{BF}(\mathrm{mm})$ the groundwater flow (baseflow) into the main channel on day $t, K_{\text {sat }}\left(\mathrm{mm} \mathrm{day}^{-1}\right)$ the hydraulic conductivity of the shallow aquifer, $\mu(-)$ the specific yield of the shallow aquifer, $L_{\mathrm{gw}}(\mathrm{m})$ the distance from the subbasin divide for the groundwater system to the main channel, Gchrg (mm) the amount of groundwater (Eq. 44) recharge entering the shallow aquifer on day $t$, and $\alpha_{\mathrm{gw}}(-)$ the baseflow recession coefficient. Equation (45) can be integrated and rearranged to calculate baseflow, according to

$$
\begin{aligned}
& \mathrm{BF}_{t}= \\
& \quad \begin{cases}0 & \text { if } \mathrm{SW}_{3} \leq \mathrm{BF}_{\text {thresh }} \\
\mathrm{BF}_{t-1} \cdot \exp ^{-\alpha_{\mathrm{gw}}+} & \text { if } \mathrm{SW}_{3}>\mathrm{BF}_{\text {thresh }} \\
\mathrm{Gchrg}_{t} \cdot\left(1-\exp ^{-\alpha_{\mathrm{gw}}}\right) & \end{cases}
\end{aligned}
$$

with $\mathrm{BF}_{t}(\mathrm{~mm})$ the baseflow into the channel on day $t$, and $\mathrm{BF}_{t-1}(\mathrm{~mm})$ the baseflow into the channel on day $t-1$. Since this equation has proven its success in the SWAT model (Neitsch et al., 2009) throughout many applications worldwide, this equation has been adopted in the SPHY model as well.

The baseflow recession coefficient $\left(\alpha_{\mathrm{gw}}\right)$ is an index that relates the baseflow response to changes in groundwater recharge. Lower values for $\alpha_{\mathrm{gw}}$ therefore correspond to areas that respond slowly to groundwater recharge, whereas higher values indicate areas that have a rapid response to groundwater recharge. The baseflow recession coefficient is generally used as a calibration parameter in the SPHY model, but a good first approximation of this coefficient can be calculated using the number of baseflow days (Neitsch et al., 2009):

$\alpha_{\mathrm{gw}}=\frac{2.3}{\mathrm{BFD}}$,

with BFD (d) the number of baseflow days, which is defined as the number of days required for baseflow recession to decline.

\subsection{Routing}

After calculating the different runoff components, the cellspecific total runoff (QTot) is calculated by adding these different runoff components. Depending on the modules being switched on, the different runoff components are i) rainfall runoff (RRo), (ii) snow runoff (SRo), (iii) glacier runoff (GRo), and iv) baseflow (BF). Rainfall runoff is the sum of surface runoff (RO, Sect. 2.7.3) and lateral flow from the first soil layer $\left(\mathrm{LF}_{1}\right.$, Sect. 2.7.4). If the groundwater module is not used, then baseflow is calculated as being the lateral flow from the second soil layer. QTot is eventually calculated according to

$\mathrm{QTot}=\mathrm{RRo}+\mathrm{SRo}+\mathrm{GRo}+\mathrm{BF}$,

with QTot $(\mathrm{mm})$ the cell-specific total runoff, RRo $(\mathrm{mm})$ rainfall runoff, SRo $(\mathrm{mm})$ snow runoff, GRo $(\mathrm{mm})$ glacier runoff, and $\mathrm{BF}(\mathrm{mm})$ baseflow from the third soil layer or lateral flow from the second soil layer. In order to obtain river discharge, QTot needs to be routed through a flow direction network. SPHY allows the user to opt between the use of a simple routing scheme (Sect. 2.8.1) or a more complex routing scheme (Sect. 2.8.2) that involves the calculation of lake outflow through $Q(h)$ relations. Both methods require a flow direction network map, which can be obtained by delineating 
a river network using PCRaster or GIS software in combination with a digital elevation model (DEM).

\subsubsection{Runoff routing}

In hydrology, streamflow routing is referred to as the transport of water through an open-channel network. Since openchannel flow is unsteady, streamflow routing often involves solving complex partial differential equations. The St. Venant equations (Brutsaert, 1971; Morris and Woolhiser, 1980) are often used for this, but these have high data requirements related to the river geometry and morphology, which are unavailable for the spatial scale SPHY is generally applied on. Additionally, solving these equations requires the use of very small time steps, which result in large model calculation times. The use of very small time steps in the St. Venant equations is required to provide numerical stability. Other models, such as, e.g., SWAT (Neitsch et al., 2009), use the Manning equation (Manning, 1989) to define the rate and velocity of river flow in combination with the variable storage (Williams, 1975) or Muskingum (Gill, 1978) routing methods to obtain river streamflow. But, the Manning equation also requires river bed dimensions, which are generally unknown on the spatial scale that SPHY generally is applied on.

Therefore, SPHY calculates for each cell the accumulated amount of water that flows out of the cell into its neighboring downstream cell. This can easily be obtained by using the accuflux PCRaster built-in function, which calculates for each cell the accumulated specific runoff from its upstream cells, including the specific runoff generated within the cell itself. If only the accuflux function is used, then it is assumed that all the specific runoff generated within the catchment on one day will end up at the most downstream location within one day, which is not plausible. Therefore, SPHY implements a flow recession coefficient $(\mathrm{kx}(-))$ that accounts for flow delay, which can be a result of channel friction. Using this coefficient, river flow in SPHY is calculated using the three equations shown below:

$$
\begin{aligned}
\mathrm{QTot}_{t}^{*} & =\frac{\mathrm{QTot}_{t} \cdot 0.001 \cdot A}{24 \cdot 3600}, \\
Q_{\mathrm{accu}, t} & =\operatorname{accuflux}\left(F_{\mathrm{dir}}, \mathrm{QTot}_{t}^{*}\right), \\
Q_{\mathrm{rout}, t} & =(1-\mathrm{kx}) \cdot Q_{\mathrm{accu}, t}+\mathrm{kx} \cdot Q_{\mathrm{rout}, t-1},
\end{aligned}
$$

with $\mathrm{QTot}_{t}^{*}\left(\mathrm{~m}^{3} \mathrm{~s}^{-1}\right)$ the specific runoff on day $t$, QTot ${ }_{t}$ the specific runoff in mm on day $t, A\left(\mathrm{~m}^{2}\right)$ the grid-cell area, $Q_{\text {accu, } t}\left(\mathrm{~m}^{3} \mathrm{~s}^{-1}\right)$ the accumulated streamflow on day $t$ without flow delay taken into account, $Q_{\text {rout }, t}\left(\mathrm{~m}^{3} \mathrm{~s}^{-1}\right)$ the routed streamflow on day $t, Q_{\text {rout }, t-1}\left(\mathrm{~m}^{3} \mathrm{~s}^{-1}\right)$ the routed streamflow on day $t-1, F_{\text {dir }}$ the flow direction network, and $\mathrm{kx}$ $(-)$ the flow recession coefficient. $\mathrm{kx}$ has values ranging between 0 and 1, where values close to 0 correspond to a fast responding catchment, and values approaching 1 correspond to a slow responding catchment.
The user can opt to route each of the four streamflow contributors separately, which may be useful if one wants to evaluate, for example, the contribution of glacier melt or snowmelt to the total routed runoff. However, this increases model run time substantially, because the accuflux function, which is a time-consuming function, needs to be called multiple times, depending on the number of flow contributors to be routed.

\subsubsection{Lake/reservoir routing}

Lakes or reservoirs act as a natural buffer, resulting in a delayed release of water from these water bodies. SPHY allows the user to choose a more complex routing scheme if lakes/reservoirs are located in their basin of interest. The use of this more advanced routing scheme requires a known relation between lake outflow and lake level height $(Q(h)$ relation) or lake storage.

To use this routing scheme, SPHY requires a nominal map with the lake cells having a unique ID, and the non-lake cells having a value of 0 . The user can supply a Boolean map with "True" for cells that have measured lake levels, and "False" for lake cells that do not have measured lake levels. This specific application of SPHY is discussed in detail in Sect. 3.3.

Four different relations can be chosen to calculate the lake outflow from the lake level height or lake storage, being (i) an exponential relation, (ii) a first-order polynomial function, (iii) a second-order polynomial function, and (iv) a thirdorder polynomial function. The user needs to supply maps containing the coefficients used in the different functions.

The lake/reservoir routing scheme simply keeps track of the actual lake storage, meaning that an initial lake storage should be supplied. Instead of the simple accuflux function described in the previous section, the lake/reservoir routing scheme uses the PCRaster functions accufractionstate and accufractionflux. The accufractionflux calculates for each cell the amount of water that is transported out of the cell, while the accufractionstate calculates the amount of water that remains stored in the cell. For non-lake cells, the fraction that is transported to the next cell is always equal to 1 , while the fraction that is transported out of a lake/reservoir cell depends on the actual lake storage. Each model time step, the lake storage is updated by inflow from upstream. Using this updated storage, the lake level and corresponding lake outflow can be calculated using one of the four relations mentioned before. The lake outflow can then be calculated as a fraction $\left(Q_{\text {frac }}(-)\right)$ of the actual lake storage. Instead of using Eq. (50), $Q_{\text {frac }}$ is then used in Eqs. (52) and (53) to calculate the accumulated streamflow and updated storage, respectively:

$$
Q_{\text {accu }, t}=\operatorname{accufractionflux}\left(F_{\mathrm{dir}}, S_{\mathrm{act}, t}, Q_{\mathrm{frac}, t}\right),
$$

$S_{\text {act }, t+1}=\operatorname{accufractionstate}\left(F_{\mathrm{dir}}, S_{\mathrm{act}, t}, Q_{\mathrm{frac}, t}\right)$,

with $S_{\text {act }, t}\left(\mathrm{~m}^{3}\right)$ and $S_{\text {act }, t+1}\left(\mathrm{~m}^{3}\right)$ the actual storage and updated storage to be used in the next time step, respectively, 
and $Q_{\text {accu, } t}\left(\mathrm{~m}^{3}\right.$ day $\left.^{-1}\right)$ the accumulated streamflow on day $t$, without flow delay taken into account. Since $Q_{\text {frac }}$ is always equal to 1 for the non-lake cells, the accufractionflux function becomes equal to the accuflux function used in the previous section. This actually means that for the river network, the same routing function from Sect. 2.8.1 is used, and that Eqs. (52) and (53) only apply to lake/reservoir cells.

In order to account for non-linearity and slower responding catchments, the same kx coefficient is used again. This involves applying Eq. (51) as a last step after Eq. (52) and converting the units from $\mathrm{m}^{3} \mathrm{day}^{-1}$ to $\mathrm{m}^{3} \mathrm{~s}^{-1}$. Since the accufractionflux and accufraction state functions are more complex to compute, the use of these functions increases model run time.

\section{Applications}

The SPHY model has been applied and tested in various studies, including real-time soil moisture predictions in lowlands, operational reservoir inflow forecasting in mountainous catchments, irrigation scenarios in the Nile basin, and climate change impact studies in the snow-glacier-rain dominated Himalayan region. Some example applications will be summarized in the following sections.

\subsection{Irrigation management in lowland areas}

As SPHY produces spatial outputs for the soil moisture content in the root zone and the potential and actual evapotranspiration (ET), it is a useful tool for application in agricultural water management decision support. By facilitating easy integration of remote sensing data, crop growth stages can be spatially assessed at different moments in time. The SPHY dynamic vegetation module ensures that all relevant soil water fluxes correspond to crop development stages throughout the growing season. Spatially distributed maps of root water content and ET deficit can be produced, enabling both the identification of locations where irrigation is required and a quantitative assessment of crop water stress.

SPHY has been applied with the purpose of providing field-specific irrigation advice for a large-scale farm in western Romania, comprising 380 individual fields and approximately ten different crops. Contrary to the other case studies highlighted in this paper, a high spatial resolution is very relevant for supporting decisions on variable-rate irrigation. The model has therefore been set up using a $30 \mathrm{~m}$ resolution, covering the 2013 and 2014 cropping seasons on a daily time step. Optical satellite data from Landsat 8 (USGS, 2013) were used as input to the dynamic vegetation module. Soil properties were derived from the Harmonized World Soil Database (Batjes et al., 2012), which for Romania contains data from the Soil Geographical Database for Europe (Lambert et al., 2003). Using the Van Genuchten equation (Van Genuchten, 1980), soil saturated water content, field capac-

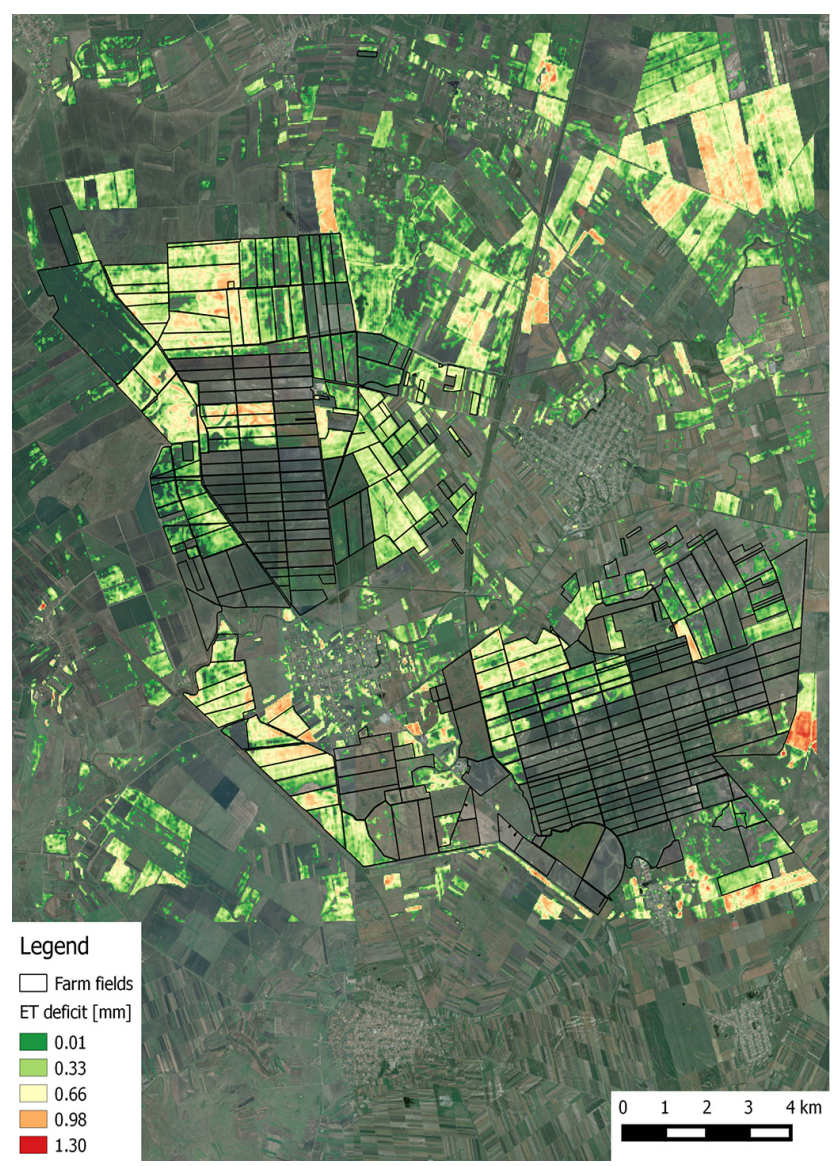

Figure 4. Spatial distribution of evapotranspiration (ET) deficit, as simulated by the SPHY model for a Romanian farm on 03 April 2014. Transparency means no ET deficit.

ity, and wilting point were determined for the HWSD classes occurring at the study site. Elevation data was obtained from the EU-DEM data set (EEA, 2014), and air temperature was measured by two on-farm weather stations.

In irrigation management applications like these, a model should be capable of simulating the moisture stress experienced by the crop due to insufficient soil moisture contents, which manifests itself by an evapotranspiration deficit (potential ET - actual ET $>0$ ). Figure 4 shows the spatial distribution of ET deficit, as simulated by the SPHY model for the entire farm on 03 April 2014. When SPHY is run in an operational setting, this spatial information can be included in a decision support system that aids the farmer in irrigation planning for the coming days.

For calibration purposes, field measurements of soil moisture and/or actual ET are desired. In this case study, one capacitance soil moisture sensor was installed in a soybean field to monitor root-zone water content shortly after 01 May 2014, which is the start of the soybean growing season. The sensor measures volumetric moisture content for every $10 \mathrm{~cm}$ of the soil profile up to a depth of $60 \mathrm{~cm}$. It is 


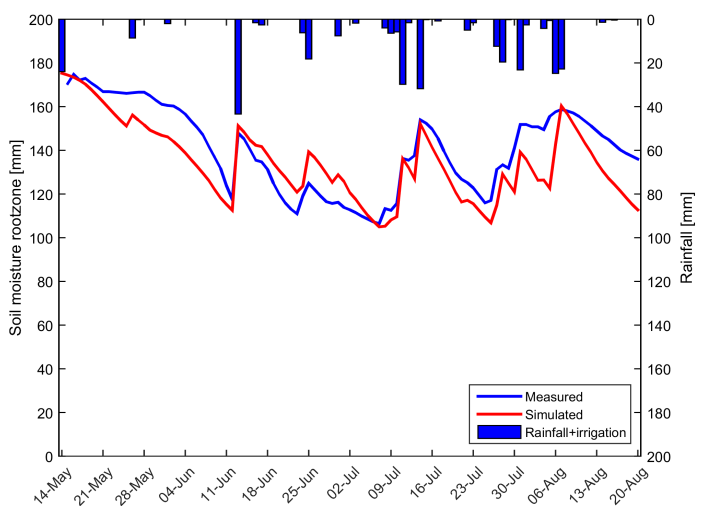

Figure 5. Measured and simulated daily root-zone soil moisture content during the 2014 growing season. Rainfall + irrigation has been measured by the rain gauge that was attached to the moisture sensor.

also equipped with a rain gauge measuring the sum of rainfall and applied irrigation water, which was used as an input to SPHY. Soil moisture measured over the extent covered by the crop root depth was averaged and compared to simulated values (Fig. 5).

Since this study was a demonstration project, only an initial model calibration was performed. The model was in this case most sensitive for the crop coefficient $(\mathrm{Kc})$, affecting the evaporative demand for water. As can be seen in Fig. 5, the temporal patterns as measured by the soil moisture sensor are well simulated by the SPHY model. Based on daily soil moisture values, a Nash-Sutcliffe (Nash and Sutcliffe, 1970) model efficiency coefficient of 0.6 was found, indicating that the quality of prediction of the SPHY model is "good" (Foglia et al., 2009). Soil moisture simulations could be further improved by conducting a full model calibration, adjusting the soil physical parameters $K_{\mathrm{sat}, 1}, \mathrm{SW}_{1, \mathrm{fc}}$, $\mathrm{SW}_{1, \mathrm{pF} 3}$, and $\mathrm{SW}_{1, \mathrm{pF} 4.2}$. Remotely sensed sensed evapotranspiration can be used in the calibration process (Immerzeel and Droogers, 2008), although such data are often not available on these small scales as ET is a very complex variable to assess (Samain et al., 2012). It should also be noted that soil moisture content is typically highly variable in space; a very high correlation between point measurements and gridcell simulations of soil moisture may therefore not always be feasible (Bramer et al., 2013).

\subsection{Snow- and glacier-fed river basins}

SPHY is being used in large Asian river basins with significant contribution of glacier melt and snowmelt to the total flow (Immerzeel et al., 2012; Lutz et al., 2012, 2014a). The major goals of these applications are two-fold.

- Assess the current hydrological regimes at high resolution; e.g., assess spatial differences in the contributions

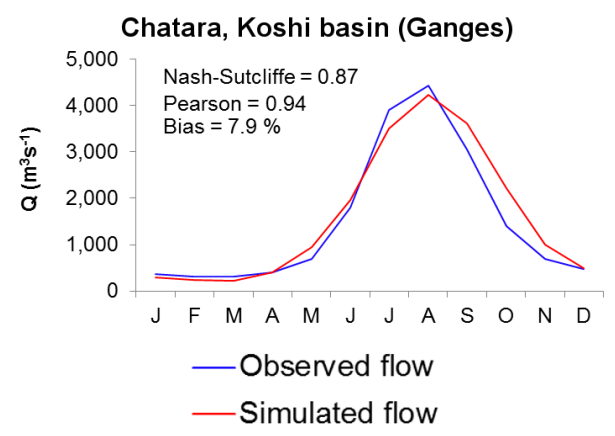

Figure 6. Average monthly observed and SPHY-simulated flow (1998-2007) for the Chatara major discharge measurement location in the Ganges basin (Lutz et al., 2014a). Metrics are calculated based on monthly time steps.

of glacier melt, snowmelt and rainfall-runoff to the total flow.

- Quantify the effects of climate change on the hydrological regimes in the future and how these affect the water availability.

Rivers originating in the high mountains of Asia are considered to be the most meltwater-dependent river systems on Earth (Schaner et al., 2012). In the regions surrounding the Himalayas and the Tibetan Plateau, large human populations depend on the water supplied by these rivers (Immerzeel et al., 2010). However, the dependency on meltwater differs strongly between river basins as a result of differences in climate and differences in basin hypsometry (Immerzeel and Bierkens, 2012). Only by using a distributed hydrological modeling approach that includes the simulation of key hydrological and cryospheric processes, and inclusion of transient changes in climate, snow cover, glaciers and runoff, can appropriate adaptation and mitigation options be developed for this region (Sorg et al., 2012). The SPHY model is very suitable for such goals, and has therefore been widely applied in the region.

For application in this region, SPHY was set up at a $1 \mathrm{~km}$ spatial resolution using a daily time step, and forced with historical air temperature $\left(T_{\mathrm{avg}}, T_{\max }, T_{\min }\right)$ and precipitation data, obtained from global and regional data sets (e.g., APHRODITE, Yatagai et al., 2012; Princeton, Sheffield et al., 2006; TRMM, Gopalan et al., 2010) or interpolated WMO station data from a historical reference period. For this historical reference period, SPHY was calibrated and validated using observed streamflow. For the future period, SPHY was forced with downscaled climate change projections obtained from general circulation models (GCMs), as available through the Climate Model Intercomparison Projects (e.g., CMIP3, Meehl et al., 2007; CMIP5, Taylor et al., 2012), which were used as a basis for the Assessment Reports prepared by the Intergovernmental Panel on Climate Change (IPCC). 
Table 3. Station locations used for calibration and validation of the SPHY model in HICAP (Lutz et al., 2014a). Three stations were used for calibration for 1998-2007. Five stations were used for an independent validation for the same period. The Nash-Sutcliffe efficiency (NS) and bias metrics were calculated at a monthly time step.

\begin{tabular}{lrrl}
\hline Location & NS (-) & Bias (\%) & Validation/calibration \\
\hline Dainyor bridge & 0.39 & 58.2 & Validation \\
Besham Qila & 0.66 & 24.7 & Validation \\
Tarbela inflow & 0.63 & 34.6 & Calibration \\
Marala inflow & 0.65 & 12.0 & Validation \\
Pachuwarghat & 0.90 & -1.6 & Validation \\
Rabuwa Bazar & 0.65 & -22.5 & Validation \\
Turkeghat & 0.87 & -5.4 & Calibration \\
Chatara & 0.87 & 7.9 & Calibration \\
\hline
\end{tabular}

In central Asia, SPHY was applied in a study (ADB, 2012; Immerzeel et al., 2012; Lutz et al., 2012) that focused on the impacts of climate change on water resources in the Amu Darya and Syr Darya river basins. SPHY was used to quantify the hydrological regimes in both basins, and subsequently to project the outflow from the upstream basins to the downstream areas by forcing the model with an ensemble of five CMIP3 GCMs. The SPHY model output fed into a water allocation model that was set up for the downstream parts of the Amu Darya and Syr Darya river basins.

In the Himalayan Climate Change Adaptation Programme (HICAP), led by the International Centre for Integrated Mountain Development (ICIMOD), SPHY has been successfully applied in the upstream basins of the Indus, Ganges, Brahmaputra, Salween and Mekong rivers (Lutz et al., 2013, 2014a). In this study the hydrological regimes of these five basins have been quantified and the calibrated and validated model (Fig. 6) was forced with an ensemble of eight GCMs to create water availability scenarios until 2050. Table 3 lists the calibration and validation results. Based on the validation results, we concluded that the model performs satisfactorily given the large scale, complexity and heterogeneity of the modeled region and data scarcity (Lutz et al., 2014a). We use one parameter set for the entire domain, which inherently means some stations perform better than others. In the particular case of the upper Indus, another possible explanation could be uncertainty in air temperature forcing in the highest parts of the upper Indus basin (locations Dainyor bridge, Besham Qila and Tarbela inflow in Table 3), since especially in this area, the used forcing data sets are based on very sparse observations. SPHY allowed the assessment of the current contribution of glacier melt and snowmelt to total flow (Fig. 7), and how total flow volumes and the intraannual distribution of river flow will change in the future (Lutz et al., 2014a).

For basins with snowmelt being an important contributor to the flow, besides calibration to observed flow, the snow-

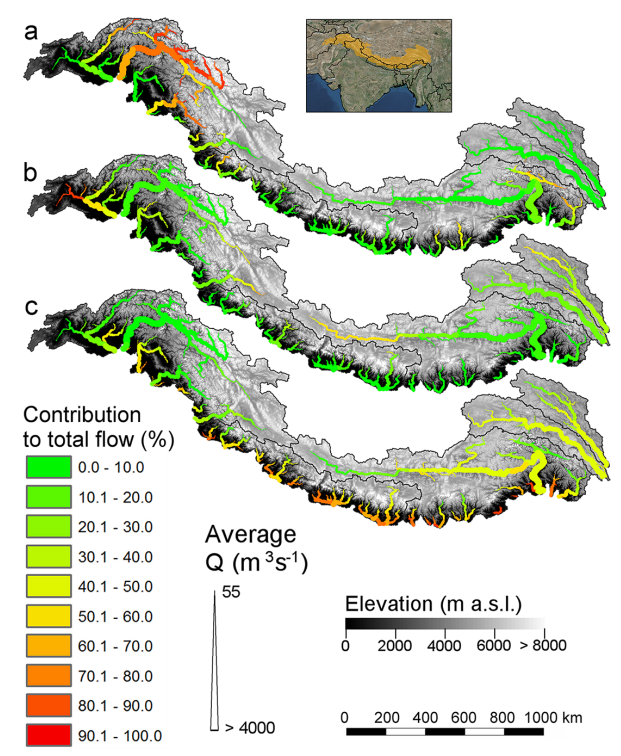

Figure 7. The contribution of glacier melt (a), snowmelt (b), and rainfall (c) to the total flow for major streams in the upstream basins of the Indus, Ganges, Brahmaputra, Salween and Mekong during 1998-2007 (Lutz et al., 2014a).

related parameters in the SPHY model can also be calibrated to observed snow cover. For the Upper Indus basin, the snowrelated parameters degree-day factor for snow $\left(\mathrm{DDF}_{\mathrm{s}}\right)$ and snow water storage capacity (SSC) were calibrated independently using MODIS snow cover imagery (Lutz et al., 2014b). The same MODIS data set was used as in Immerzeel et al. (2009). From the beginning of 2000 until halfway through 2008, the snow cover imagery was averaged for 46 different periods of 8 days ( 5 days for the last period) to generate 46 different average snow cover maps. For example, period 1 is the average snow cover for 01-08 January for 2000 until 2008, whereas period 2 is the average snow cover for 09-16 January for 2000 until 2008, etc. The SPHY model was run for 2000-2007 at a daily time step and, for each $1 \times 1 \mathrm{~km}$ grid cell, the average snow cover was calculated for the same 46 periods as in the MODIS observed snow cover data set. Subsequently, these simulated snow cover maps were resampled to $0.05^{\circ}$ spatial resolution, which is the native resolution of the MODIS product. Figure 8 shows the basin-average observed and simulated fractional snow cover for the 46 periods during 2000-2007 and Fig. 9 shows the same at the $0.05^{\circ}$ grid-cell level. As a final step, the baseflow recession coefficient $\left(\alpha_{\mathrm{gw}}\right)$ and routing coefficient $(\mathrm{kx})$ were calibrated to match the simulated streamflow with the observed streamflow.

\subsection{Flow forecasting}

In data-scarce environments and inaccessible mountainous terrain, like in the Chilean Andes, it is often difficult to install instrumentation and retrieve real-time physical data from 


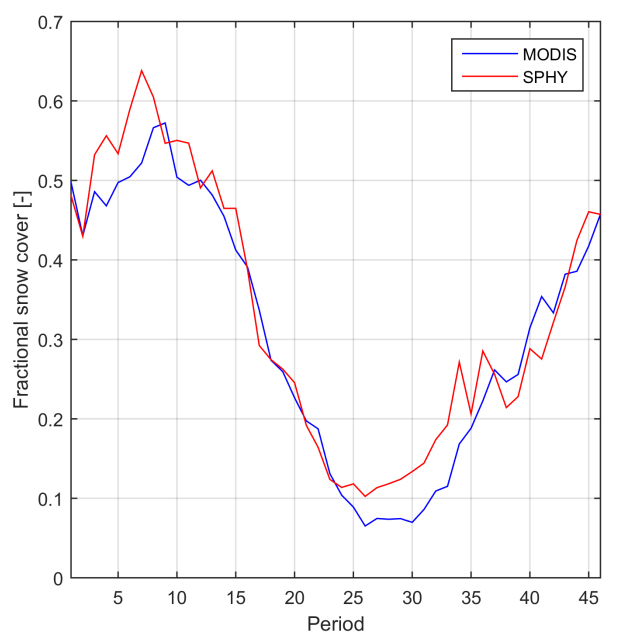

Figure 8. Observed and simulated average fractional snow cover in the upper Indus basin. The values represent the 9-year average for 46 (8-day) periods during 2000-2007.

these instruments. These real-time data can be useful to capture the hydroclimatic variability in this region, and improve the forecasting capability of hydrological models. Although statistical models can provide skillful seasonal forecasts, using large-scale climate variables and in situ data (Piechota and Chiew, 1998; Grantz et al., 2005; Regonda et al., 2006; Bracken et al., 2010), a particular hydropower company in Chile was mainly interested in the potential use of an integrated system, using measurements derived from both Earth observation (EO) satellites and in situ sensors, to force a hydrological model to forecast seasonal streamflow during the snow melting season. The objective of the INTOGENER (INTegration of EO data and GNSS-R signals for ENERgy applications) project was therefore to demonstrate the operational forecasting capability of the SPHY model in datascarce environments with large hydroclimatic variability.

During INTOGENER, data retrieved from EO satellites consisted of a DEM and a time series of snow cover maps. Snow cover images were retrieved on a weekly basis, using RADARSAT and MODIS (Parajka and Blöschl, 2008; Hall et al., 2002) imagery. These images were used to update the snow storage (SS $(\mathrm{mm})$ ) in the model in order to initialize it for the forecasting period. Figure 10 shows the snow storage as simulated by the SPHY model during the snow melting season in the Laja basin. These maps clearly show the capability of SPHY to simulate the spatial variation of snow storage, with more snow on the higher elevations, and a decrease in snow storage throughout the melting season. Discharge, precipitation and temperature data were collected using in situ meteorological stations. In order to calculate the lake outflow accurately, the SPHY model was initialized with water level measurements retrieved from reflected Global Navigation Satellite System (GNSS) signals in Laja Lake. Static data that were used in the SPHY model
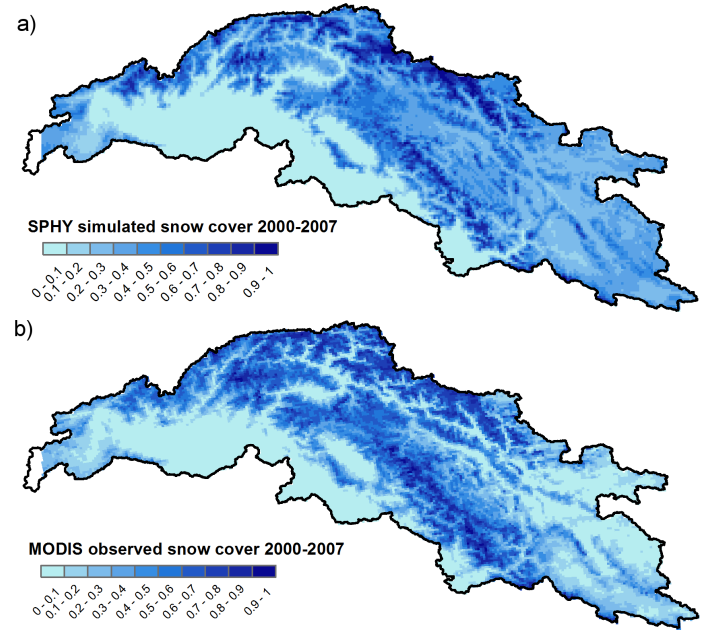

Figure 9. (a) SPHY simulated snow cover 2000-2007 and (b) MODIS observed snow cover 2000-2007.

consisted of soil characteristics derived from the Harmonized World Soil Database (HWSD) (Batjes et al., 2009) and land use data obtained from the GLOBCOVER (Bontemps et al., 2011) product. The SPHY model was set up to run at a spatial resolution of $200 \mathrm{~m}$.

Figure 11 shows the observed vs. simulated daily streamflow for two locations within the Laja River basin for the historical period 2007-2008. It can be seen that model performance is quite satisfactory for both locations, with volume errors of -4 and $-9.4 \%$ for the Abanico Canal (downstream of Lake Laja) and Rio Laja en Tucapel, respectively. The NS coefficient, which is especially useful for assessing the simulation of high discharge peaks, is less satisfactory for these locations. Hydropower companies, however, have more interest in expected flow volumes for the coming weeks/months than in accurate day-to-day flow simulations, and therefore the NS coefficient is less important in this case. If the NS coefficient is calculated for the same period on a monthly basis, then the NS coefficients are 0.53 for the Abanico Canal and 0.81 for Rio Laja en Tucapel. It is likely that SPHY model performance would even have been better if a full model calibration would have been performed.

The hydropower company's main interest is the model's capacity to predict the total expected flow for the coming weeks during the melting season (October 2013 through March 2014). To forecast streamflow during the snow melting season, the SPHY model was forced with gridded temperature and precipitation data from the European Centre for Medium-range Weather Forecasts (ECMWF) Seasonal Forecasting System (SEAS) (Andersson, 2013). The SEAS model provided daily forecasts at a spatial resolution of $0.75^{\circ}, 7$ months ahead, and was used to forecast streamflow up till the end of the melting season. Figure 12 shows the bias between the total cumulative forecasted flow and observed flow for the 23 model runs that were executed during 


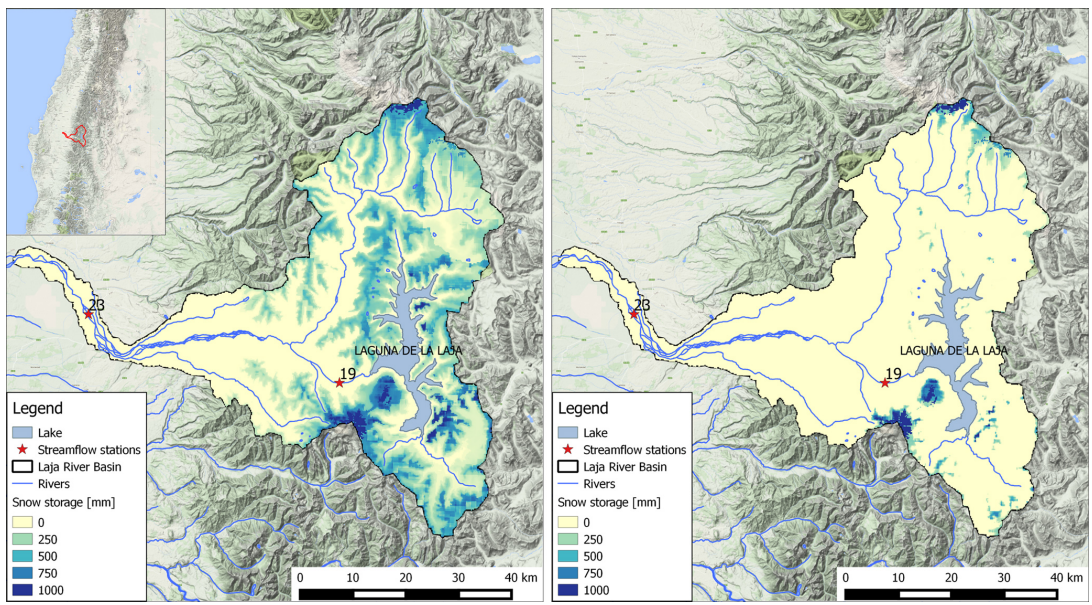

Figure 10. Snow storage (mm) as simulated by the SPHY model on 12 August (left) and 01 October (right) during the snow melting season of 2013 in the Laja River basin.

operational mode. Although there are some bias fluctuations in the Rio Laja en Tucapel model runs, it can be concluded that the bias decreases for each next model run for both locations, which is a logical result of a decreasing climate forcing uncertainty as the model progresses in time. It can be seen that the SPHY model streamflow forecasts for Canal Abanico, which is downstream of Laja Lake, are substantially better than for Rio Laja en Tucapel (the most downstream location). The reason for this has not been investigated during the demonstration study, but since model performance for these two locations was satisfactory during calibration, a plausible explanation could be the larger climate forecast uncertainty in the higher altitude areas (Hijmans et al., 2005; Rollenbeck and Bendix, 2011; Vicuña et al., 2011; McPhee et al., 2010; Mendoza et al., 2012; Ragettli and Pellicciotti, 2012; Ragettli et al., 2015) in the northeastern part of the basin that contributes to the streamflow of Rio Laja en Tucapel. Additionally, only two in situ meteorological stations were available during operational mode, whereas during calibration, 20+ meteorological stations were available. Moreover, these operational meteorological stations were not installed at higher altitudes, where precipitation patterns tend to be spatially very variable (Wagner et al., 2012; Rollenbeck and Bendix, 2011).

\section{Future outlook}

Further development and refinement of the SPHY model are foreseen in seven areas, including (i) the implementation of time steps shorter than 1 day, (ii) evapotranspiration processes, (iii) depression storage, (iv) representation of lakes/reservoirs, (v) streamflow routing, (vi) cryospheric processes, and (vii) the development of a graphical user interface.
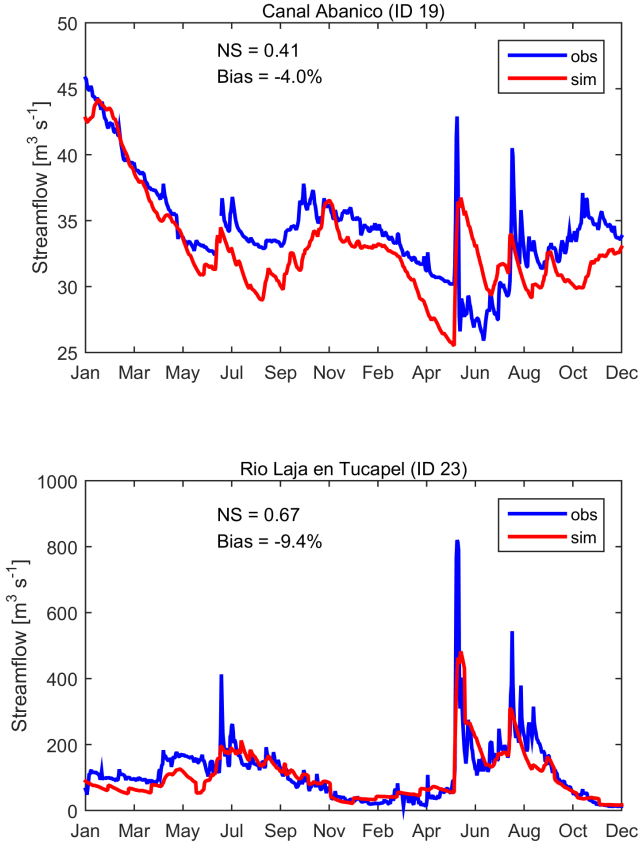

Figure 11. Daily observed vs. SPHY simulated streamflow (period 2007-2008) for the streamflow stations Canal Abanico (ID 19) and Rio Laja en Tucapel (ID 23). The Nash-Sutcliffe (NS) and bias model performance indicators are shown as well.

Currently, the SPHY model can only run at a daily time step. The implementation of hourly model time steps is foreseen for future SPHY versions, which allows other processes, like, e.g., Hortonian runoff (Beven, 2004; Corradini et al., 1998), to be included as well. Using hourly instead of daily climate forcings will improve other processes as well, such as snowmelt and glacier melt.

The current version of the SPHY model calculates the reference evapotranspiration using the modified Hargreaves 

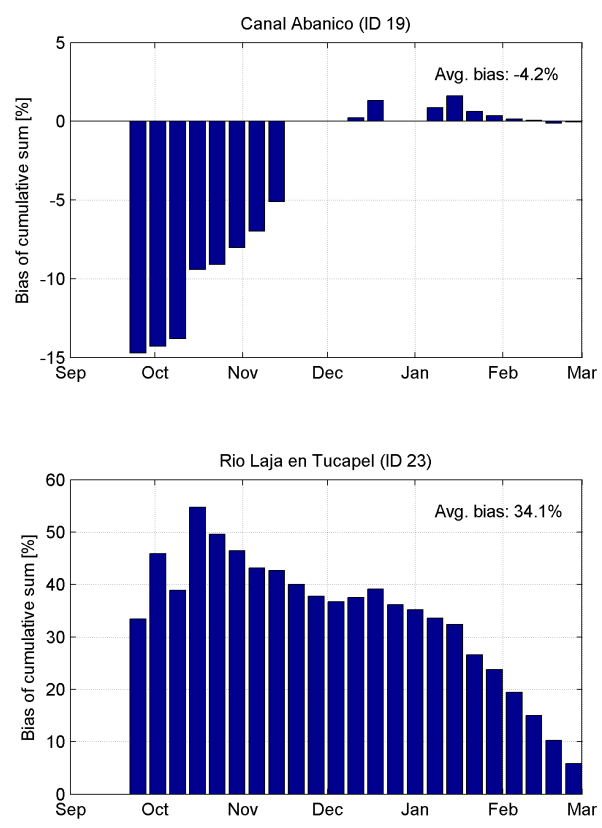

Figure 12. Bias between total cumulative forecasted flow and observed flow for the 23 model runs that were executed between the end of September 2013 and March 2014. Results are shown for the locations Canal Abanico (ID 19) and Rio Laja en Tucapel (ID 23).

equation (Hargreaves and Samani, 1985), which requires three meteorological variables: the average, maximum and minimum daily air temperature. Although this method is less data demanding than the well-known Penman-Monteith (Allen et al., 1998) equation, additional methods for the calculation of the reference evapotranspiration that are even less data demanding should be explored for future versions of the SPHY model.

Besides the dynamic simulation of a time-varying fractional vegetation coverage, using NDVI time series as input, it is currently assumed that the root depth of a growing crop is constant throughout the simulation period, and that it is equal to the depth of the first soil layer. In reality, a crop is seeded, starts to develop its root system, and finally gets harvested. Although this root development process is less dynamical for forests and therefore more relevant for agricultural crops, it can be seen as an improvement to be included in the SPHY model. A similar approach as in the SWAP model (van Dam et al., 1997) could be used, where the user needs to define the root depths for each growing stage. However, it should be taken into account that the SWAP model is a field-scale model for which crop-specific root depth information is generally available, and that SPHY is generally applied on larger spatial scales where cropping calendars, and thus corresponding root depth information is harder to obtain.

Surface runoff in SPHY occurs whenever excess rainfall results in saturation of the first soil layer. Subsequently, this excess rainfall leaves the grid cell as surface runoff without any obstacles or friction, and enters the river system within the same day. In reality, surface runoff can be delayed because of surface friction, or stored in local depressions or man-made ponds (surface irrigation), before it is released to the river system. The concept of having a ponding layer is mainly beneficial for (i) agricultural applications where surface irrigation in combination with a ponding layer plays a major role, e.g., rice irrigation, and/or (ii) if the model is run at very high spatial resolution where the role of local depressions becomes more prominent; water can be stored for hours/days in these depressions, and water may be partly or completely evaporated before it has the chance to flow to the channels. The effect of delayed surface runoff can be related to dense vegetation or agricultural land management practices (Hunink et al., 2013; Kauffman et al., 2014), with bench terraces and contour tillage being examples of these practices. The effect of delayed or stored surface runoff is currently not implemented in the model, but should be further explored for future versions.

As was mentioned in Sect. 2.8.2, each individual lake is represented by a maximum of one grid cell in SPHY. This is related to the PCRaster flow direction calculation: each cell needs to flow to a downstream cell, and the total flow in the most downstream cell should be equal to the accumulated flow of all upstream cells plus the flow generated within that cell. This means that large lakes, consisting of multiple neighboring cells, can be seen as an enormous pit in the flow direction network, meaning that streamflow routing from the upstream lake cells is interrupted at these pit cells. Since large lakes can evaporate a substantial amount of water (Gat et al., 1994), a lake-cell merging procedure should be developed for future versions of the SPHY model that allows one to automatically re-create the flow direction network based on the locations of the lake inflow cells and outflow cell, such that all the accumulated water of the inflow cells is allocated and stored in the downstream cell, where it can continue its way downstream.

Although the currently implemented routing scheme in SPHY has proven its success during various applications (see Sects. 3.2 and 3.3), improvements in the routing scheme are foreseen for future SPHY versions. Using the current approach, it is assumed that the open channel surface area equals the grid-cell area. If coarse model resolutions are used, then this assumption becomes less plausible, because in reality the surface area of a river would only cover a small fraction of this grid-cell area. Therefore, it would be interesting to explore using more advanced routing schemes that take into account the river's cross-section dimensions and corresponding velocity flow rates. An example of a more advanced routing scheme that takes into account the channel dimensions, and has been found to yield good results under a wide range of conditions in natural rivers (Brutsaert, 2005), is the Muskingum method (Gill, 1978). Considering the larger spatial resolutions that SPHY is generally applied for, it seems almost infeasible to determine the channel dimensions. How- 
ever, some empirical relations between the bank-full discharge and channel dimensions are available (Park, 1977), and should be explored for implementation in SPHY.

Sublimation of snow is an important component of the water balance in areas experiencing snow cover during significant times of the year (Strasser et al., 2008). Different approaches have been developed to estimate this flux in hydrological models (Bowling et al., 2004; MacDonald et al., 2009; Lenaerts et al., 2010; Groot Zwaaftink et al., 2013). Development of a parameterization of sublimation using the low data requirement of SPHY is foreseen.

In SPHY, glaciers are considered entities generating melt using a temperature-index model. Improvements in the representation of glaciers are foreseen to make them mass conserving, e.g., considering the precipitation falling in their accumulation areas. In the current SPHY version, all surface runoff that is generated on glacier-covered areas is considered glacier melt, and inclusion of further specification to seasonal snowmelt and glacier ice melt is foreseen. Besides, the temperature-index model can be improved by including the incoming radiation in addition to air temperature in the temperature-index model (Hock, 2003; Pellicciotti et al., 2005; Heynen et al., 2013). Additionally, the glacier module will be extended with a parameterization for modeling glacier dynamics, which would enable quantification of the retreat or advance of glaciers as a result of climate perturbations.

When SPHY is run at a spatial resolution of $1 \mathrm{~km}$ or coarser for mountainous regions, improvement of the representation of sub-grid processes becomes useful. For example, when the daily average air temperature for a given $1 \mathrm{~km}$ grid cell is $0^{\circ} \mathrm{C}$, no melt will be simulated for that grid cell, although the sub-grid variability in elevation shows that part of the grid cell is lower than the average elevation of the grid cell and thus has temperatures above $0{ }^{\circ} \mathrm{C}$, resulting in the generation of meltwater.

Although the model is relatively easy to understand and applicable by hydrologists and scientists with basic skills, it would be better if the model could be used by a wider group of users with basic hydrological and computer skills. Therefore, the objective of an ongoing project is to develop a graphical user interface (GUI) for the SPHY model. This GUI will be developed as a plugin for the open-source QGIS environment, making it easy to set up the model and analyze model input and output spatially and temporally.

\section{Conclusions}

The objective of this paper is to introduce and present the SPHY model, its development background, and demonstrate some example applications. SPHY has been developed with the explicit aim of simulating terrestrial hydrology under various physiographical and hydroclimatic conditions by integrating key components from existing and well-tested mod- els. SPHY (i) integrates most hydrologic processes, (ii) has the flexibility to be applied in a wide range of hydrologic applications, and (iii) on various scales, and (iv) can easily be implemented.

The most relevant hydrological processes that are integrated into the SPHY model are rainfall-runoff processes, cryosphere processes, evapotranspiration processes, the simulation of dynamic vegetational cover, lake/reservoir outflow, and the simulation of root-zone moisture contents. The capability of SPHY to successfully simulate rainfall-runoff and cryosphere processes was proven during its applications in the snow- and glacier-fed river basins in Asia, and in Chile, where it was used to forecast streamflow during the snow melting season. Both the applications in Chile and in Romania show the easy implementation of SPHY to include remote sensing data as dynamic model input: in Chile, remotely sensed snow cover was used to implement a time-variable fractional snow coverage, and in Romania the NDVI was used to simulate dynamic vegetational cover. The glacierfed river basins in Asia application also showed the potential use of remote sensing data, where remotely sensed snow cover was used to calibrate the simulated snow cover by the SPHY model. Whereas the application in the glacier-fed river basins in Asia to study the effects of climate change on the available water resources is an example of the use of SPHY to support strategic decision-making, the application in Romania for real-time irrigation support, and the application in Chile to support hydropower companies for their reservoir management, are examples of the use of SPHY for operational purposes. The different spatial resolutions and physiographical and hydroclimatic regions in which SPHY was applied demonstrate its flexibility in scaling: in Romania it was applied at the farm level, requiring a spatial resolution of $30 \mathrm{~m}$, whereas in Chile and Asia it was applied at the river basin scale at resolutions varying from $200 \mathrm{~m}$ to $1 \mathrm{~km}$. The modular framework of SPHY enables it to be applied over a broad range of oreographical and climatological conditions as demonstrated in this paper: the agricultural focus in Romania allowed for switching off of the glaciers, snow, and routing modules, whereas these modules were switched on for the Asian and Chilean applications. Decreased model run time and minimized input data requirements were the resulting benefits in cases where modules are switched off.

In summary, it can be concluded that SPHY is a model that can be easily implemented for strategic decision-making as well as for operational support, having the flexibility to integrate the hydrological processes that are relevant for the area of application, and have the flexibility to be applicable under a wide range and scale of applications. 


\section{Appendix A: SPHY model parameters}

Table A1. Overview of SPHY model parameters. The last column indicates whether the parameter is observable, or can be determined by calibration (free).

\begin{tabular}{|c|c|c|c|}
\hline Acronym & Description & Units & Parameter determination \\
\hline $\mathrm{Kc}$ & Crop coefficient & - & Free \\
\hline $\mathrm{Kc}_{\max }$ & Maximum crop coefficient & - & Free \\
\hline $\mathrm{Kc}_{\min }$ & Minimum crop coefficient & - & Free \\
\hline $\mathrm{NDVI}_{\max }$ & Maximum NDVI & - & Observable \\
\hline $\mathrm{NDVI}_{\min }$ & Minimum NDVI & - & Observable \\
\hline FPAR $_{\max }$ & Maximum fraction of absorbed photosynthetically active radiation & - & Free \\
\hline FPAR $_{\min }$ & Minimum fraction of absorbed photosynthetically active radiation & - & Free \\
\hline$T_{\text {crit }}$ & Temperature threshold for precipitation to fall as snow & ${ }^{\circ} \mathrm{C}$ & Free \\
\hline $\mathrm{DDF}_{\mathrm{S}}$ & Degree-day factor for snow & $\mathrm{mm}^{\circ} \mathrm{C}^{-1}$ day $^{-1}$ & Free \\
\hline SSC & Water storage capacity of snowpack & $\mathrm{mm} \mathrm{mm}^{-1}$ & Free \\
\hline GlacF & Glacier fraction of grid cell & - & Observable \\
\hline $\mathrm{DDF}_{\mathrm{CI}}$ & Degree-day factor for debris-free glaciers & $\mathrm{mm}^{\circ} \mathrm{C}^{-1}$ day $^{-1}$ & Free \\
\hline $\mathrm{DDF}_{\mathrm{DC}}$ & Degree-day factor for debris-covered glaciers & $\mathrm{mm}^{\circ} \mathrm{C}^{-1}$ day $^{-1}$ & Free \\
\hline$F_{\mathrm{CI}}$ & Fraction of GlacF that is debris free & - & Observable \\
\hline$F_{\mathrm{DC}}$ & Fraction of GlacF that is covered with debris & - & Observable \\
\hline GlacROF & Fraction of glacier melt that becomes glacier runoff & - & Free \\
\hline $\mathrm{SW}_{1, \mathrm{sat}}$ & Saturated soil water content of first soil layer & $\mathrm{mm}$ & Observable \\
\hline $\mathrm{SW}_{1, \mathrm{fc}}$ & Field capacity of first soil layer & $\mathrm{mm}$ & Observable \\
\hline $\mathrm{SW}_{1, \mathrm{pF} 3}$ & Wilting point of first soil layer & $\mathrm{mm}$ & Observable \\
\hline $\mathrm{SW}_{1, \mathrm{pF} 4.2}$ & Permanent wilting point of first soil layer & $\mathrm{mm}$ & Observable \\
\hline$K_{\text {sat } 1}$ & Saturated hydraulic conductivity of first soil layer & $\mathrm{mm} \mathrm{day}^{-1}$ & Observable \\
\hline $\mathrm{SW}_{2, \text { sat }}$ & Saturated soil water content of second soil layer & $\mathrm{mm}$ & Observable \\
\hline $\mathrm{SW}_{2, \mathrm{fc}}$ & Field capacity of second soil layer & $\mathrm{mm}$ & Observable \\
\hline$K_{\text {sat }, 2}$ & Saturated hydraulic conductivity of second soil layer & $m m$ day $^{-1}$ & Observable \\
\hline $\mathrm{SW}_{3, \text { sat }}$ & Saturated soil water content of groundwater layer & $\mathrm{mm}$ & Observable \\
\hline $\operatorname{slp}$ & Slope of grid cell & $\mathrm{m} \mathrm{m}^{-1}$ & Observable \\
\hline$\delta_{\mathrm{gw}}$ & Groundwater recharge delay time & day & Free \\
\hline$\alpha_{\mathrm{gw}}$ & Baseflow recession coefficient & day $^{-1}$ & Free \\
\hline $\mathrm{BF}_{\text {tresh }}$ & Threshold for baseflow to occur & $\mathrm{mm}$ & Free \\
\hline $\mathrm{kx}$ & Flow recession coefficient & - & Free \\
\hline
\end{tabular}




\section{Code availability}

The SPHY model is available as executable (sphy.exe) and source code, where the source code consists of the following files:

$$
\begin{aligned}
& \text { - sphy_config.cfg } \\
& \text { - sphy.py } \\
& \text { - hargreaves.py } \\
& \text { - dynamic_veg.py } \\
& \text { - snow.py } \\
& \text { - rootzone.py } \\
& \text { - ET.py } \\
& \text { - subzone.py } \\
& \text { - glacier.py } \\
& \text { - groundwater.py } \\
& \text { - routing.py } \\
& \text { - reservoir_routing.py } \\
& \text { - reporting.py } \\
& \text { - timecalc.py }
\end{aligned}
$$

The order in which the model algorithms are executed is defined in the sphy.py file, in which the required modules are imported depending on the settings in sphy_config.cfg. Model settings (parameters, input and output) can be modified in the sphy_config.cfg configuration file. It is mandatory to have this file and the source code (or model executable) in the same folder on the PC's hard drive. If the user opts to run the SPHY model using the model's source code, then the SPHY model is executed by entering "python.exe sphy.py" in the windows command prompt. Otherwise, the model can be executed by entering "sphy.exe" in the windows command prompt. Both the model source code and its executable can be obtained from the SPHY model website (http://www.sphy.nl).

In order to run the SPHY model v2.0, it is required to have the following software installed on your pc:

- Python 2.7.6 (32 bit)

- NumPy 1.8.0 (32 bit)

- PCRaster 4.0 (32 bit)

Acknowledgements. The authors would like to thank ICIMOD, the Asian Development Bank, and the European Space Agency for the financial support that enabled the development of the SPHY model.

Edited by: H. McMillan

\section{References}

Abbott, M., Bathurst, J., Cunge, J., O'Connell, P., and Rasmussen, J.: An introduction to the European Hydrological System Systeme Hydrologique Europeen, "SHE", 2: Structure of a physically-based, distributed modelling system, J. Hydrol., 87, 61-77, 1986.

ADB: Consultant's Report Regional Technical Assistance: Water and Adaptation Interventions in Central and West Asia, Tech. rep., 2012.

Allen, R. G., Pereira, L. S., Raes, D., and Smith, M.: Crop evapotranspiration - Guidelines for computing crop water requirements, FAO Irrigation and drainage paper, 56, 1998.

Andersson, E.: User guide to ECMWF forecast products. Version 1.1, Tech. rep., ECMWF, available at: http://old.ecmwf. int/products/forecasts/guide/user_guide.pdf (last access: $02 \mathrm{Au}-$ gust 2014), 2013.

Bartholomeus, R. P., Witte, J.-P. M., van Bodegom, P. M., van Dam, J. C., and Aerts, R.: Critical soil conditions for oxygen stress to plant roots: Substituting the Feddesfunction by a process-based model, J. Hydrol., 360, 147-165, doi:10.1016/j.jhydrol.2008.07.029, 2008.

Bastiaanssen, W., Allen, R., Droogers, P., Da'Urso, G., and Steduto, P.: Twenty-five years modeling irrigated and drained soils: State of the art, Agr. Water Manage., 92, 111-125, doi:10.1016/j.agwat.2007.05.013, 2007.

Batjes, N., Dijkshoorn, K., van Engelen, V., Fischer, G., Jones, A., Montanarella, L., Petri, M., Prieler, S., Teixeira, E., Wiberg, D., and Shi, X.: Harmonized World Soil Database (version 1.1), Tech. rep., FAO and IIASA, Rome, Italy and Laxenburg, Austria, 2009.

Batjes, N., Dijkshoorn, K., van Engelen, V., Fischer, G., Jones, A., Montanarella, L., Petri, M., Prieler, S., Teixeira, E., Wiberg, D., and Shi, X.: Harmonized World Soil Database (version 1.2), Tech. rep., FAO and IIASA, Rome, Italy and Laxenburg, Austria, 2012.

Beven, K.: Kinematic subsurface stormflow, Water Resour. Res., 17, 1419-1424, doi:10.1029/WR017i005p01419, 1981.

Beven, K.: Robert E. Horton's perceptual model of infiltration processes, Hydrol. Process., 18, 3447-3460, doi:10.1002/hyp.5740, 2004.

Beven, K. and Germann, P.: Macropores and water flow in soils, Water Resour. Res., 18, 1311-1325, doi:10.1029/WR018i005p01311, 1982.

Bierkens, M. F. P. and van Beek, L. P. H.: Seasonal Predictability of European Discharge: NAO and Hydrological Response Time, J. Hydrometeorol., 10, 953-968, doi:10.1175/2009JHM1034.1, 2009.

Biswas, A. K. and Tortajada, C.: Future Water Governance: Problems and Perspectives, Int. J. Water Resour. D., 26, 129-139, doi:10.1080/07900627.2010.488853, 2010.

Bontemps, S., Defourny, P., van Bogaert, E., Arino, O., Kalogirou, V., and Ramos Perez, J.: GLOBCOVER 2009. Products Description and Validation Report, Tech. rep., ESA, 2011.

Bowling, L. C., Pomeroy, J. W., and Lettenmaier, D. P.: Parameterization of Blowing-Snow Sublimation in a Macroscale Hydrology Model, J. Hydrometeorol., 5, 745-762, doi:10.1175/15257541(2004)005<0745:POBSIA>2.0.CO;2, 2004. 
Bracken, C., Rajagopalan, B., and Prairie, J.: A multisite seasonal ensemble streamflow forecasting technique, Water Resour. Res., 46, doi:10.1029/2009WR007965, 2010.

Bramer, L. M., Hornbuckle, B. K., and Caragea, P. C.: How Many Measurements of Soil Moisture within the Footprint of a Ground-Based Microwave Radiometer Are Required to Account for Meter-Scale Spatial Variability?, Vadose Zone J., 12, 3, doi:10.2136/vzj2012.0100, 2013.

Brutsaert, W.: De Saint-Venant Equations Experimentally Verified, J. Hydr. Eng. Div.-ASCE, 97, 1387-1401, 1971.

Brutsaert, W.: Hydrology. An introduction., Cambridge University Press, Cambridge, 2005.

Carlson, T. N. and Ripley, D. A.: On the relation between NDVI, fractional vegetation cover, and leaf area index, Remote Sens. Environ., 62, 241-252, doi:10.1016/S0034-4257(97)00104-1, 1997.

Clark, M. P., Slater, A. G., Rupp, D. E., Woods, R. A., Vrugt, J. A., Gupta, H. V., Wagener, T., and Hay, L. E.: Framework for Understanding Structural Errors (FUSE): A modular framework to diagnose differences between hydrological models, Water Resour. Res., 44, W00B02, doi:10.1029/2007WR006735, 2008.

Clark, M. P., Nijssen, B., Lundquist, J. D., Kavetski, D., Rupp, D. E., Woods, R. A., Freer, J. E., Gutmann, E. D., Wood, A. W., Brekke, L. D., Arnold, J. R., Gochis, D. J., and Rasmussen, R. M.: A unified approach for process-based hydrologic modeling: 1. Modeling concept, Water Resour. Res., 51, 2498-2514, doi:10.1002/2015WR017198, 2015a.

Clark, M. P., Nijssen, B., Lundquist, J. D., Kavetski, D., Rupp, D. E., Woods, R. A., Freer, J. E., Gutmann, E. D., Wood, A. W., Gochis, D. J., Rasmussen, R. M., Tarboton, D. G., Mahat, V., Flerchinger, G. N., and Marks, D. G.: A unified approach for process-based hydrologic modeling: 2. Model implementation and case studies, Water Resour. Res., 51, 2515-2542, doi:10.1002/2015WR017200, 2015b.

Contreras, S., Hunink, J., and Baille, A.: Building a Watershed Information System for the Campo de Cartagena basin (Spain) integrating hydrological modeling and remote sensing. FutureWater Report 125., Tech. rep., FutureWater, 2014.

Corradini, C., Morbidelli, R., and Melone, F.: On the interaction between infiltration and Hortonian runoff, J. Hydrol., 204, 5267, doi:10.1016/S0022-1694(97)00100-5, 1998.

Dai, A.: Drought under global warming: a review, Wiley Interdisciplinary Reviews: Climate Change, 2, 45-65, doi:10.1002/wcc.81, 2011.

de Jong, S. and Jetten, V.: Distributed, quantitative assessment of canopy storage capacity by Hyperspectral Remote Sensing, available at: http://www.geo.uu.nl/dejong/pdf-files/ Interception-by-RS.pdf (last access: 13 November 2014), 2010.

Deb, S. and Shukla, M.: Soil hydrology, land use and agriculture: measurement and modelling, Las Cruces, doi:10.1079/9781845937973.0000, 2011.

Droogers, P. and Aerts, J.: Adaptation strategies to climate change and climate variability: A comparative study between seven contrasting river basins, Phys. Chem. Earth Pt. A/B/C, 30, 339-346, doi:10.1016/j.pce.2005.06.015, 2005.

Droogers, P. and Bouma, J.: Simulation modelling for water governance in basins, Int. J. Water Resour. D., 30, 475-494, doi:10.1080/07900627.2014.903771, 2014.
Droogers, P. and Immerzeel, W. W.: Wat is het beste model?, H2O Tijdschrift voor watervoorziening en waterbeheer, 4, 3841, 2010.

Droogers, P., Immerzeel, W. W., Terink, W., Hoogeveen, J., Bierkens, M. F. P., van Beek, L. P. H., and Debele, B.: Water resources trends in Middle East and North Africa towards 2050, Hydrol. Earth Syst. Sci., 16, 3101-3114, doi:10.5194/hess-163101-2012, 2012.

EEA: EU-DEM layers, Copernicus data and information funded by the European Union, European Environmental Agency, Tech. rep., 2014.

Endrizzi, S., Dall' Amico, M., Gruber, S., and Rigon, R.: GEOtop Users Manual. User Manual Version 1.0, Tech. rep., Department of Physical Geography, University of Zurich, Zurich, 2011.

Endrizzi, S., Gruber, S., Dall'Amico, M., and Rigon, R.: GEOtop 2.0: simulating the combined energy and water balance at and below the land surface accounting for soil freezing, snow cover and terrain effects, Geosci. Model Dev., 7, 2831-2857, doi:10.5194/gmd-7-2831-2014, 2014.

EPA: Modeling at EPA, available at: http://www.epa.gov/epahome/ models.htm (last access: 30 September 2014), 2014.

Essery, R., Morin, S., Lejeune, Y., and B Ménard, C.: A comparison of 1701 snow models using observations from an alpine site, Adv. Water Resour., 55, 131-148, doi:10.1016/j.advwatres.2012.07.013, 2013

FAO: FAO Water. Crop Water Information, available at: http://www. fao.org/nr/water/cropinfo.html (last access: 09 June 2014), 2013.

Feddes, R., Kowalik, P., and Zaradny, H.: Simulation of field water use and crop yield. Simulation Monographs, Pudoc, Wageningen University, 1978.

Finger, D., Pellicciotti, F., Konz, M., Rimkus, S., and Burlando, P.: The value of glacier mass balance, satellite snow cover images, and hourly discharge for improving the performance of a physically based distributed hydrological model, Water Resour. Res., 47, W07519, doi:10.1029/2010WR009824, 2011.

Foglia, L., Hill, M. C., Mehl, S. W., and Burlando, P.: Sensitivity analysis, calibration, and testing of a distributed hydrological model using error-based weighting and one objective function, Water Resour. Res., 45, W06427, doi:10.1029/2008WR007255, 2009.

Gat, J. R., Bowser, C. J., and Kendall, C.: The contribution of evaporation from the Great Lakes to the continental atmosphere: estimate based on stable isotope data, Geophys. Res. Lett., 21, 557560, doi:10.1029/94GL00069, 1994.

Gill, M. A.: Flood routing by the Muskingum method, J. Hydrol., 36, 353-363, doi:10.1016/0022-1694(78)90153-1, 1978.

Gopalan, K., Wang, N.-Y., Ferraro, R., and Liu, C.: Status of the TRMM 2A12 Land Precipitation Algorithm, J. Atmos. Ocean. Tech., 27, 1343-1354, doi:10.1175/2010JTECHA1454.1, 2010.

Goward, S. N. and Huemmrich, K. F.: Vegetation canopy PAR absorptance and the normalized difference vegetation index: An assessment using the SAIL model, Remote Sens. Environ., 39, 119-140, doi:10.1016/0034-4257(92)90131-3, 1992.

Grantz, K., Rajagopalan, B., Clark, M., and Zagona, E.: A technique for incorporating large-scale climate information in basinscale ensemble streamflow forecasts, Water Resour. Res., 41, doi:10.1029/2004WR003467, 2005. 
Groot Zwaaftink, C. D., Mott, R., and Lehning, M.: Seasonal simulation of drifting snow sublimation in Alpine terrain, Water Resour. Res., 49, 1581-1590, doi:10.1002/wrcr.20137, 2013.

Hall, D. K., Riggs, G. A., Salomonson, V. V., DiGirolamo, N. E., and Bayr, K. J.: MODIS snow-cover products, Remote Sens. Environ., 83, 181-194, doi:10.1016/S0034-4257(02)00095-0, 2002.

Hargreaves, G. H. and Samani, Z. A.: Reference Crop Evapotranspiration from Temperature, Appl. Eng. Agric., 1, 96-99, doi:10.13031/2013.26773, 1985.

HEC: Hydrologic Engineering Center (HEC) computer software for hydrologic engineering and planning analysis, available at: http: //www.hec.usace.army.mil/software/ (last access: 03 September 2014), 2014.

Hewlett, J.: Soil moisture as a source of base flow from steep mountain watershed, Tech. rep., US forest Service, Southeastern Forest Experiment Station, Asheville, North Carolina, 1961.

Heynen, M., Pellicciotti, F., and Carenzo, M.: Parameter sensitivity of a distributed enhanced temperature-index melt model, Ann. Glaciol., 54, 311-321, doi:10.3189/2013AoG63A537, 2013.

Hijmans, R. J., Cameron, S. E., Parra, J. L., Jones, P. G., and Jarvis, A.: Very high resolution interpolated climate surfaces for global land areas, Int. J. Climatol., 25, 1965-1978, doi:10.1002/joc.1276, 2005.

Hock, R.: Temperature index melt modelling in mountain areas, J. Hydrol., 282, 104-115, doi:10.1016/S0022-1694(03)00257-9, 2003.

Hock, R.: Glacier melt: a review of processes and their modelling, Prog. Phys. Geog., 29, 362-391, doi:10.1191/0309133305pp453ra, 2005.

Hooghoudt, S.: Bijdragen tot de kennis van eenige natuurkundige grootheden van den grond. No. 7. Algemeene beschouwing van het probleem van de detailontwatering en de infiltratie door middel van parallel loopende drains, greppels, slooten en kanalen, Versl. Landbouwkd. Onderz., 46, 515-707, 1940.

Hunink, J., Niadas, I., Antonaropoulos, P., Droogers, P., and de Vente, J.: Targeting of intervention areas to reduce reservoir sedimentation in the Tana catchment (Kenya) using SWAT, Hydrolog. Sci. J., 58, 600-614, doi:10.1080/02626667.2013.774090, 2013.

Immerzeel, W. and Droogers, P.: Calibration of a distributed hydrological model based on satellite evapotranspiration, J. Hydrol., 349, 411-424, doi:10.1016/j.jhydrol.2007.11.017, 2008.

Immerzeel, W., Lutz, A., and Droogers, P.: Climate Change Impacts on the Upstream Water Resources of the Amu and Syr Darya River Basins, Tech. rep., FutureWater, Wageningen, 2012.

Immerzeel, W. W. and Bierkens, M. F. P.: Asia's water balance, Nat. Geosci., 5, 841-842, doi:10.1038/ngeo1643, 2012.

Immerzeel, W. W., Droogers, P., de Jong, S. M., and Bierkens, M. F. P.: Large-scale monitoring of snow cover and runoff simulation in Himalayan river basins using remote sensing, Remote Sens. Environ., 113, 40-49, doi:10.1016/j.rse.2008.08.010, 2009.

Immerzeel, W. W., van Beek, L. P. H., and Bierkens, M. F. P.: Climate change will affect the Asian water towers, Science, 328, 1382-1385, doi:10.1126/science.1183188, 2010.

Immerzeel, W. W., Beek, L. P. H., Konz, M., Shrestha, A. B., and Bierkens, M. F. P.: Hydrological response to climate change in a glacierized catchment in the Himalayas, Climatic Change, 110, 721-736, doi:10.1007/s10584-011-0143-4, 2011.
Irrisoft: Database and on-line Applications in Irrigation, Drainage \& Hydrology, available at: http://www.irrisoft.org (last access: 07 May 2014), 2014.

Karssenberg, D.: The value of environmental modelling languages for building distributed hydrological models, Hydrol. Process., 16, 2751-2766, doi:10.1002/hyp.1068, 2002.

Karssenberg, D., Burrough, P. A., Sluiter, R., and de Jong, K.: The PCRaster Software and Course Materials for Teaching Numerical Modelling in the Environmental Sciences, T. GIS, 5, 99-110, doi:10.1111/1467-9671.00070, 2001.

Karssenberg, D., Schmitz, O., Salamon, P., de Jong, K., and Bierkens, M. F.: A software framework for construction of process-based stochastic spatio-temporal models and data assimilation, Environ. Model. Softw., 25, 489-502, doi:10.1016/j.envsoft.2009.10.004, 2010.

Kauffman, S., Droogers, P., Hunink, J., Mwaniki, B., Muchena, F., Gicheru, P., Bindraban, P., Onduru, D., Cleveringa, R., and Bouma, J.: Green Water Credits - exploring its potential to enhance ecosystem services by reducing soil erosion in the Upper Tana basin, Kenya, International Journal of Biodiversity Science, Ecosystem Services \& Management, 10, 133-143, doi:10.1080/21513732.2014.890670, 2014.

Kokkonen, T., Koivusalo, H., Jakeman, A., and Norton, J.: Construction of a Degree-Day Snow Model in the Light of the "Ten Iterative Steps in Model Development", in: Proceedings of the iEMSs Third Biennial Meeting: Summit on Environmental Modelling and Software, Environmental Modelling and Software Society, Burlington, USA, 2006.

Kozak, J. A., Ahuja, L. R., Green, T. R., and Ma, L.: Modelling crop canopy and residue rainfall interception effects on soil hydrological components for semi-arid agriculture, Hydrol. Process., 21, 229-241, doi:10.1002/hyp.6235, 2007.

Krysanova, V., Müller-Wohlfeil, D.-I., and Becker, A.: Development and test of a spatially distributed hydrological/water quality model for mesoscale watersheds, Ecol. Model., 106, 261-289, 1998.

Krysanova, V., Wechsung, F., Arnold, J., Srinivasan, R., and Williams, J.: PIK Report Nr. 69 "SWIM (Soil and Water Integrated Model), User Manual”, Tech. rep., Potsdam Institute for Climate Impact Research, Potsdam, 2000.

Krysanova, V., Hattermann, F., Huang, S., Hesse, C., Vetter, T., Liersch, S., Koch, H., and Kundzewicz, Z. W.: Modelling climate and land-use change impacts with SWIM: lessons learnt from multiple applications, Hydrolog. Sci. J., 60, 606-635, doi:10.1080/02626667.2014.925560, 2015.

Lall, U.: Debates - The future of hydrological sciences: A (common) path forward? One water. One world. Many climes. Many souls, Water Resour. Res., 50, 5335-5341, doi:10.1002/2014WR015402, 2014.

Lambert, J., Daroussin, J., Eimberck, M., Le Bas, C., Jamagne, M., King, D., and Montanarella, L.: Soil Geographical Database for Eurasia \& The Mediterranean. Instructions Guide for Elaboration at scale 1:1,000,000 version 4.0. EUR 20422 EN., Tech. rep., JRC, Ispra, Italy, 2003.

Lenaerts, J. T. M., van den Broeke, M. R., Déry, S. J., KönigLanglo, G., Ettema, J., and Munneke, P. K.: Modelling snowdrift sublimation on an Antarctic ice shelf, The Cryosphere, 4, 179190, doi:10.5194/tc-4-179-2010, 2010. 
Liang, X., Lettenmaier, D. P., Wood, E. F., and Burges, S. J.: A simple hydrologically based model of land surface water and energy fluxes for general circulation models, 99, 14415-14428, doi:10.1029/94JD00483, 1994.

Liang, X., Wood, E. F., and Lettenmaier, D. P.: Surface soil moisture parameterization of the VIC-2L model: Evaluation and modification, Global Planet. Change, 13, 195-206, doi:10.1016/09218181(95)00046-1, 1996.

Lindström, G., Pers, C., Rosberg, J., Strömqvist, J., and Arheimer, B.: Development and testing of the HYPE (Hydrological Predictions for the Environment) water quality model for different spatial scales, Hydrol. Res., 41, 295-319, doi:10.2166/nh.2010.007, 2010.

Liu, Y., Gupta, H., Springer, E., and Wagener, T.: Linking science with environmental decision making: Experiences from an integrated modeling approach to supporting sustainable water resources management, Environ. Model. Softw., 23, 846-858, doi:10.1016/j.envsoft.2007.10.007, 2008.

Lutz, A. F., Droogers, P., and Immerzeel, W.: Climate Change Impact and Adaptation on the Water Resources in the Amu Darya and Syr Darya River Basins, Tech. rep., FutureWater, Wageningen, 2012.

Lutz, A. F., Immerzeel, W. W., Gobiet, A., Pellicciotti, F., and Bierkens, M. F. P.: Comparison of climate change signals in CMIP3 and CMIP5 multi-model ensembles and implications for Central Asian glaciers, Hydrol. Earth Syst. Sci., 17, 3661-3677, doi:10.5194/hess-17-3661-2013, 2013.

Lutz, A. F., Immerzeel, W. W., Shrestha, A. B., and Bierkens, M. F. P.: Consistent increase in High Asia's runoff due to increasing glacier melt and precipitation, Nature Climate Change, 4, 587592, doi:10.1038/nclimate2237, 2014a.

Lutz, A. F., Immerzeel, W., and Kraaijenbrink, P.: Gridded Meteorological Datasets and Hydrological Modelling in the Upper Indus Basin. FutureWater Report 130, Tech. rep., FutureWater, Wageningen, the Netherlands, 2014b.

MacDonald, M. K., Pomeroy, J. W., and Pietroniro, A.: Parameterizing redistribution and sublimation of blowing snow for hydrological models: tests in a mountainous subarctic catchment, Hydrol. Process., 23, 2570-2583, doi:10.1002/hyp.7356, 2009.

Manning, R.: On the flow of water in open channels and pipes, Trans. Inst. Civ. Eng. Ireland, 20, 161-207, 1989.

McPhee, J., Rubio-Alvarez, E., Meza, R., Ayala, A., Vargas, X., and Vicuna, S.: An approach to estimating hydropower impacts of climate change from a regional perspective, Watershed Management, 2010, 13-24, doi:10.1061/41143(394)2, 2010.

Meehl, G. A., Covey, C., Taylor, K. E., Delworth, T., Stouffer, R. J., Latif, M., McAvaney, B., and Mitchell, J. F. B.: THE WCRP CMIP3 Multimodel Dataset: A New Era in Climate Change Research, B. Am. Meteorol. Soc., 88, 1383-1394, doi:10.1175/BAMS-88-9-1383, 2007.

Mendoza, P. A., McPhee, J., and Vargas, X.: Uncertainty in flood forecasting: A distributed modeling approach in a sparse data catchment, Water Resour. Res., 48, W09532, doi:10.1029/2011WR011089, 2012.

Morris, E. M. and Woolhiser, D. A.: Unsteady one-dimensional flow over a plane: Partial equilibrium and recession hydrographs, Water Resour. Res., 16, 355-360, doi:10.1029/WR016i002p00355, 1980.
Myneni, R. and Williams, D.: On the relationship between FAPAR and NDVI, Remote Sens. Environ., 49, 200-211, doi:10.1016/0034-4257(94)90016-7, 1994.

Nash, J. and Sutcliffe, J.: River flow forecasting through conceptual models part I - A discussion of principles, J. Hydrol., 10, 282 290, doi:10.1016/0022-1694(70)90255-6, 1970.

Neitsch, S. L., Arnold, J. G., Kiniry, J. R., and Williams, J. R.: Soil and Water Assessment Tool (SWAT). Theoretical Documentation, version 2009, Tech. rep., Texas Water Resources Institute, College Station, Texas, available at: http://twri.tamu.edu/reports/ 2011/tr406.pdf (last access: 04 June 2014), 2009.

Niu, G. Y., Yang, Z. L., Mitchell, K. E., Chen, F., Ek, M. B., Barlage, M., Kumar, A., Manning, K., Niyogi, D., Rosero, E., Tewari, M., and Xia, Y.: The community Noah land surface model with multiparameterization options (Noah-MP): 1. Model description and evaluation with local-scale measurements, J. Geophys. Res.Atmos., 116, D12109, doi:10.1029/2010JD015139, 2011.

Oogathoo, S., Prasher, S., Rudra, R., and Patel, R.: Calibration and validation of the MIKE SHE model in Canagagigue Creek watershed, in: Agricultural and biosystems engineering for a sustainable world. International Conference on Agricultural Engineering, Hersonissos, Crete, Greece, 2008.

Parajka, J. and Blöschl, G.: Spatio-temporal combination of MODIS images - potential for snow cover mapping, Water Resour. Res., 44, W03406, doi:10.1029/2007WR006204, 2008.

Park, C. C.: World-wide variations in hydraulic geometry exponents of stream channels: An analysis and some observations, J. Hydrol., 33, 133-146, doi:10.1016/0022-1694(77)90103-2, 1977.

Pechlivanidis, I., Jackson, B., McIntyre, N., and Weather, H.: Catchment scale hydrological modelling: a review of model types, calibration approaches and uncertainty analysis methods in the context of recent developments in technology and applications, Global NEST Journal, 13, 193-214, 2011.

Pellicciotti, F., Brock, B., Strasser, U., Burlando, P., Funk, M., and Corripio, J.: An enhanced temperature-index glacier melt model including the shortwave radiation balance: development and testing for Haut Glacier d'Arolla, Switzerland, J. Glaciol., 51, 573587, doi:10.3189/172756505781829124, 2005.

Peng, D., Zhang, B., and Liu, L.: Comparing spatiotemporal patterns in Eurasian FPAR derived from two NDVI-based methods, International Journal of Digital Earth, 5, 283-298, doi:10.1080/17538947.2011.598193, 2012.

Piechota, T. and Chiew, F.: Seasonal streamflow forecasting in eastern Australia and the El Niño - Southern Oscillation, Water Resour. Res., 34, 3035-3044, 1998.

Pomeroy, J. W., Gray, D. M., Brown, T., Hedstrom, N. R., Quinton, W. L., Granger, R. J., and Carey, S. K.: The cold regions hydrological model: A platform for basing process representation and model structure on physical evidence, Hydrol. Process., 21, 2650-2667, doi:10.1002/hyp.6787, 2007.

Rafn, E. B., Contor, B., and Ames, D. P.: Evaluation of a Method for Estimating Irrigated Crop-Evapotranspiration Coefficients from Remotely Sensed Data in Idaho, J. Irrig. Drain. E.-ASCE, 134, 722-729, doi:10.1061/(ASCE)07339437(2008)134:6(722), 2008.

Ragettli, S. and Pellicciotti, F.: Calibration of a physically based, spatially distributed hydrological model in a glacierized basin: On the use of knowledge from glaciometeorological processes 
to constrain model parameters, Water Resour. Res., 48, W03509, doi:10.1029/2011WR010559, 2012.

Ragettli, S., Cortés, G., Mcphee, J., and Pellicciotti, F.: An evaluation of approaches for modelling hydrological processes in highelevation, glacierized Andean watersheds, Hydrol. Process., 28, 5674-5695, doi:10.1002/hyp.10055, 2014.

Ragettli, S., Pellicciotti, F., Immerzeel, W., Miles, E., Petersen, L., Heynen, M., Shea, J. M., Stumm, D., Joshi, S., and Shrestha, A.: Unraveling the hydrology of a Himalayan watershed through integration of high resolution in-situ data and remote sensing with an advanced simulation model, Adv. Water Resour., 78, 94-111, doi:10.1016/j.advwatres.2015.01.013, 2015.

Refshaard, J. and Storm, B.: MIKE SHE, Danish Hydraulic Institute, Horsholm, 1995.

Regonda, S. K., Rajagopalan, B., Clark, M., and Zagona, E.: A multimodel ensemble forecast framework: Application to spring seasonal flows in the Gunnison River Basin, Water Resour. Res., 42, W09404, doi:10.1029/2005WR004653, 2006.

Reid, T. D., Carenzo, M., Pellicciotti, F., and Brock, B. W.: Including debris cover effects in a distributed model of glacier ablation, J. Geophys. Res.-Atmos., 117, D18105, doi:10.1029/2012JD017795, 2012.

Rigon, R., Bertoldi, G., and Over, T. M.: GEOtop: A Distributed Hydrological Model with Coupled Water and Energy Budgets, J. Hydrometeorol., 7, 371-388, doi:10.1175/JHM497.1, 2006.

Rockström, J., Falkenmark, M., Lannerstad, M., and Karlberg, L.: The planetary water drama: Dual task of feeding humanity and curbing climate change, Geophys. Res. Lett., 39, L15401, doi:10.1029/2012GL051688, 2012.

Rollenbeck, R. and Bendix, J.: Rainfall distribution in the Andes of southern Ecuador derived from blending weather radar data and meteorological field observations, Atmos. Res., 99, 277-289, doi:10.1016/j.atmosres.2010.10.018, 2011.

Samain, B., Simons, G. W. H., Voogt, M. P., Defloor, W., Bink, N.-J., and Pauwels, V. R. N.: Consistency between hydrological model, large aperture scintillometer and remote sensing based evapotranspiration estimates for a heterogeneous catchment, Hydrol. Earth Syst. Sci., 16, 2095-2107, doi:10.5194/hess-16-20952012, 2012.

Samaniego, L., Kumar, R., and Attinger, S.: Multiscale parameter regionalization of a grid-based hydrologic model at the mesoscale, Water Resour. Res., 46, W05523, doi:10.1029/2008WR007327, 2010.

Sangrey, D. A., Harrop-Williams, K. O., and Klaiber, J. A.: Predicting Ground-Water Response to Precipitation, J. Geotech. Eng.-ASCE, 110, 957-975, doi:10.1061/(ASCE)07339410(1984)110:7(957), 1984.

Schaner, N., Voisin, N., Nijssen, B., and Lettenmaier, D. P.: The contribution of glacier melt to streamflow, Environ. Res. Lett., 7, 034029, doi:10.1088/1748-9326/7/3/034029, 2012.

Schmitz, O., Karssenberg, D., van Deursen, W., and Wesseling, C.: Linking external components to a spatiotemporal modelling framework: Coupling MODFLOW and PCRaster, Environ. Model. Softw., 24, 1088-1099, doi:10.1016/j.envsoft.2009.02.018, 2009.

Schmitz, O., Karssenberg, D., de Jong, K., de Kok, J.-L., and de Jong, S. M.: Map algebra and model algebra for integrated model building, Environ. Model. Softw., 48, 113-128, doi:10.1016/j.envsoft.2013.06.009, 2013.
Sellers, P. J., Tucker, C. J., Collatz, G. J., Los, S. O., Justice, C. O., Dazlich, D. A., and Randall, D. A.: A Revised Land Surface Parameterization (SiB2) for Atmospheric GCMS. Part II: The Generation of Global Fields of Terrestrial Biophysical Parameters from Satellite Data, J. Climate, 9, 706-737, doi:10.1175/15200442(1996)009<0706:ARLSPF>2.0.CO;2, 1996.

Sheffield, J., Goteti, G., and Wood, E. F.: Development of a 50Year High-Resolution Global Dataset of Meteorological Forcings for Land Surface Modeling, J. Climate, 19, 3088-3111, doi:10.1175/JCLI3790.1, 2006.

Singh, P. and Kumar, N.: Impact assessment of climate change on the hydrological response of a snow and glacier melt runoff dominated Himalayan river, J. Hydrol., 193, 316-350, doi:10.1016/S0022-1694(96)03142-3, 1997.

Sloan, P. G. and Moore, I. D.: Modeling subsurface stormflow on steeply sloping forested watersheds, Water Resour. Res., 20, 1815-1822, doi:10.1029/WR020i012p01815, 1984.

Smedema, L. and Rycroft, D.: Land Drainage: Planning and Design of Agricultural Drainage Systems, Cornell University Press, 1983.

Sorg, A., Bolch, T., Stoffel, M., Solomina, O., and Beniston, M.: Climate change impacts on glaciers and runoff in Tien Shan (Central Asia), Nature Climate Change, 2, 725-731, doi:10.1038/nclimate1592, 2012.

Sperna Weiland, F. C., van Beek, L. P. H., Kwadijk, J. C. J., and Bierkens, M. F. P.: The ability of a GCM-forced hydrological model to reproduce global discharge variability, Hydrol. Earth Syst. Sci., 14, 1595-1621, doi:10.5194/hess-14-15952010, 2010.

Strasser, U., Bernhardt, M., Weber, M., Liston, G. E., and Mauser, W.: Is snow sublimation important in the alpine water balance?, The Cryosphere, 2, 53-66, doi:10.5194/tc-2-53-2008, 2008.

Taylor, K. E., Stouffer, R. J., and Meehl, G. A.: An Overview of CMIP5 and the Experiment Design, B. Am. Meteorol. Soc., 93, 485-498, doi:10.1175/BAMS-D-11-00094.1, 2012.

Tucker, C. J.: Red and photographic infrared linear combinations for monitoring vegetation, Remote Sens. Environ., 8, 127-150, doi:10.1016/0034-4257(79)90013-0, 1979.

USGS: Landsat 8: U.S. Geological Survey Fact Sheet 2013-3060, Tech. rep., available at: http://pubs.usgs.gov/fs/2013/3060/ (last access: 15 June 2014), 2013.

USGS: Water Resources Applications Software, available at: http://water.usgs.gov/software/lists/alphabetical (last access: 30 April 2014), 2014.

van Beek, L. and Bierkens, M.: The Global Hydrological Model PCR-GLOBWB: Conceptualization, Parameterization and Verification, Tech. rep., Department of Physical Geography, Utrecht University, Utrecht, available at: http://vanbeek.geo.uu. nl/suppinfo/vanbeekbierkens2009.pdf (last access: 24 November 2014), 2008.

van Dam, J. C., Huygen, J., Wesseling, J. G., Feddes, R. A., Kabat, P., van Walsum, P. E. V., Groenendijk, P., and van Diepen, C. A.: Theory of SWAP version 2.0. Simulation of water flow, solute transport and plant growth in the Soil-Water-Atmosphere-Plant environment, Tech. rep., Department Water Resources, Wageningen Agricultural University, 1997.

Van Der Knijff, J. M., Younis, J., and De Roo, A. P. J.: LISFLOOD: a GIS-based distributed model for river basin scale water bal- 
ance and flood simulation, Int. J. Geogr. Inf. Sci., 24, 189-212, doi:10.1080/13658810802549154, 2010.

Van der Kwaak, J. E. and Loague, K.: Hydrologic-response simulations for the R-5 catchment with a comprehensive physics-based model, Water Resour. Res., 37, 999-1013, doi:10.1029/2000WR900272, 2001.

Van Genuchten, M.: A closed-form equation for predicting the hydraulic conductivity of unsaturated soils, Soil Sci. Soc. Am. J., 44, 892-898, 1980.

Venetis, C.: A STUDY ON THE RECESSION OF UNCONFINED ACQUIFERS, International Association of Scientific Hydrology. Bulletin, 14, 119-125, doi:10.1080/02626666909493759, 1969.

Verbunt, M., Gurtz, J., Jasper, K., Lang, H., Warmerdam, P., and Zappa, M.: The hydrological role of snow and glaciers in alpine river basins and their distributed modeling, J. Hydrol., 282, 3655, doi:10.1016/S0022-1694(03)00251-8, 2003.

Vicuña, S., Garreaud, R. D., and McPhee, J.: Climate change impacts on the hydrology of a snowmelt driven basin in semiarid Chile, Climatic Change, 105, 469-488, doi:10.1007/s10584-0109888-4, 2011.

Von Hoyningen-Huene, J.: Die Interzeption des Niederschlags in landwirtschaftlichen Pflanzenbeständen, Arbeitsbericht Deutscher Verband fur Wasserwirtschaft und Kulturbau, DWK, 1981.

Wada, Y., Van Beek, L. P. H., Van Kempen, C. M., Reckman, J. W. T. M., Vasak, S., and Bierkens, M. F. P.: Global depletion of groundwater resources, Geophys. Res. Lett., 37, L20402, doi:10.1029/2010GL044571, 2010.
Wagener, T., Sivapalan, M., Troch, P. A., McGlynn, B. L., Harman, C. J., Gupta, H. V., Kumar, P., Rao, P. S. C., Basu, N. B., and Wilson, J. S.: The future of hydrology: An evolving science for a changing world, Water Resour. Res., 46, W05301, doi:10.1029/2009WR008906, 2010.

Wagner, P. D., Fiener, P., Wilken, F., Kumar, S., and Schneider, K.: Comparison and evaluation of spatial interpolation schemes for daily rainfall in data scarce regions, J. Hydrol., 464-465, 388400, doi:10.1016/j.jhydrol.2012.07.026, 2012.

Wheeler, T. and von Braun, J.: Climate change impacts on global food security, Science, 341, 508-513, doi:10.1126/science.1239402, 2013.

Wigmosta, M. S., Vail, L. W., and Lettenmaier, D. P.: A distributed hydrology-vegetation model for complex terrain, Water Resour. Res., 30, 1665-1680, doi:10.1029/94WR00436, 1994.

Williams, J.: HYMO flood routing, J. Hydrol., 26, 17-27, doi:10.1016/0022-1694(75)90122-5, 1975.

Yatagai, A., Kamiguchi, K., Arakawa, O., Hamada, A., Yasutomi, N., and Kitoh, A.: APHRODITE: Constructing a Long-Term Daily Gridded Precipitation Dataset for Asia Based on a Dense Network of Rain Gauges, B. Am. Meteorol. Soc., 93, 1401-1415, doi:10.1175/BAMS-D-11-00122.1, 2012. 